Engineer Research and

Development Center

Regional Sediment Management (RSM) Program

Nearshore Placement Techniques in Southern Lake Michigan

David E. Arnold, Brian C. McFall, Katherine E. Brutsché,

March 2018

Erin C. Maloney, and David F. Bucaro

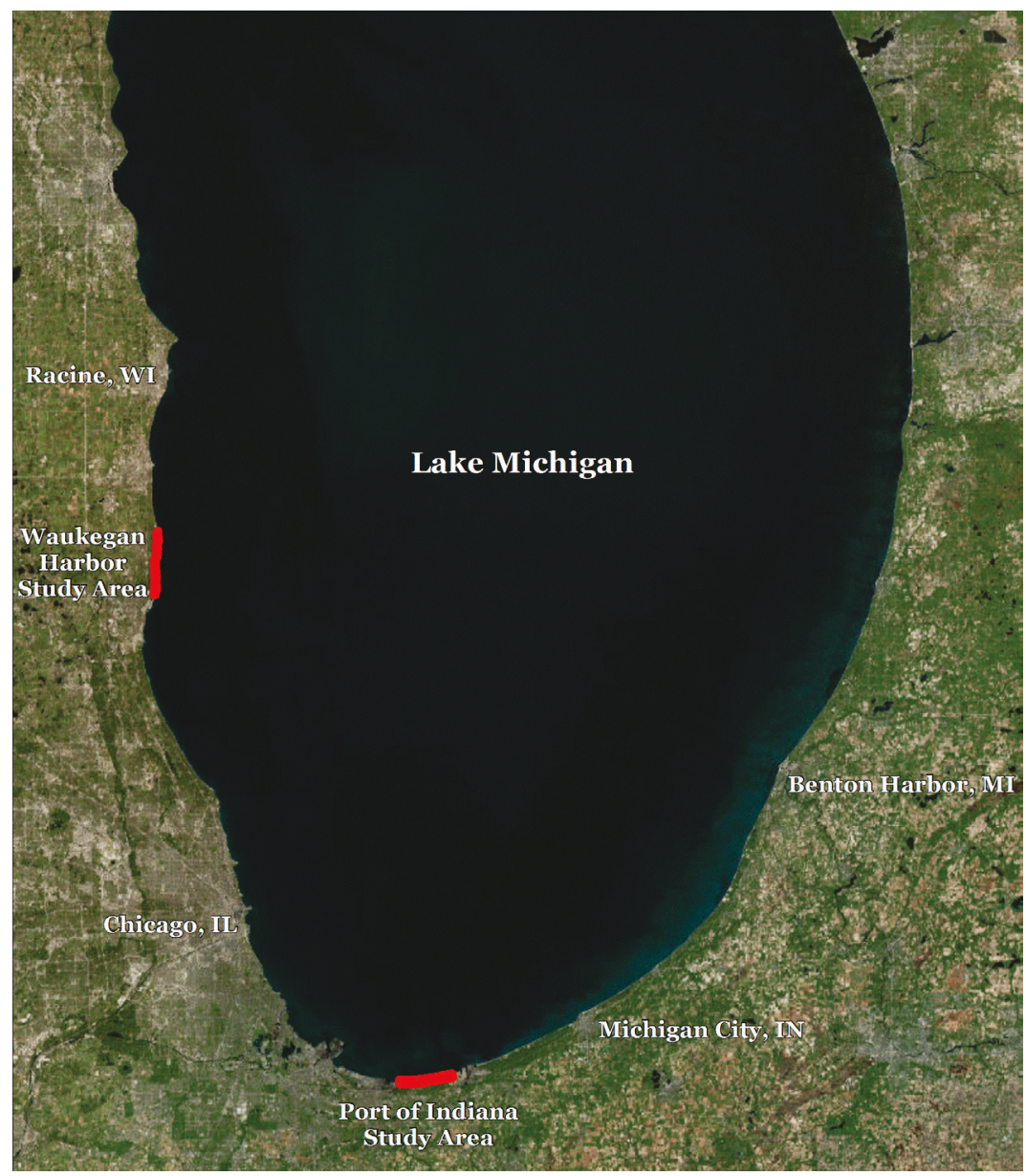


The U.S. Army Engineer Research and Development Center (ERDC) solves the nation's toughest engineering and environmental challenges. ERDC develops innovative solutions in civil and military engineering, geospatial sciences, water resources, and environmental sciences for the Army, the Department of Defense, civilian agencies, and our nation's public good. Find out more at www.erdc.usace.army.mil.

To search for other technical reports published by ERDC, visit the ERDC online library at http://acwc.sdp.sirsi.net/client/default. 


\section{Nearshore Placement Techniques in Southern Lake Michigan}

David E. Arnold, Brian C. McFall, and Katherine E. Brutsché

Coastal and Hydraulics Laboratory

U.S. Army Engineer Research and Development Center

3909 Halls Ferry Road, Building 3200

Vicksburg, Mississippi 39180-6199

Erin C. Maloney and David F. Bucaro

U.S. Army Corps of Engineers, Chicago District

231 S. LaSalle Street, Suite 1500

Chicago, Illinois 60604

Final report

Approved for public release; distribution is unlimited.

Prepared for U.S. Army Corps of Engineers

Washington, DC 20314-1000

Under Project 462581, "Evaluation of Nearshore Placement in Southern Lake Michigan" 


\section{Abstract}

The shorelines near the Port of Indiana and Waukegan Harbor in southern Lake Michigan were analyzed using historical aerial photography, direct beach and nearshore placement records, and the U.S. Geological Survey Digital Shoreline Analysis System. The shoreline analysis was compared to the results of the U.S. Army Corps of Engineers Sediment Mobility Tool. High water levels and significant storms led to erosive conditions in the 1980s. During the 1990 s and 2000s, nearshore placement of locally dredged sediment likely contributed to the recovery of these shorelines. The current nearshore placement technique consists of placing sediment in 5.5 meters ( 18 feet) of water in small discrete mounds to prevent the sediment from obstructing the hanging gates of the scow from closing. The sediment will be mobilized more frequently, and more energy will be dissipated if the dredged sediment is placed in shallower depths in the shape of an elongated bar or mound. Two potential methods to accomplish this are to restrict the placement area for a project to a much smaller area in the larger permitted nearshore placement area and to light load the scows to reduce the draft for shallower placement.

DISCLAIMER: The contents of this report are not to be used for advertising, publication, or promotional purposes. Citation of trade names does not constitute an official endorsement or approval of the use of such commercial products. All product names and trademarks cited are the property of their respective owners. The findings of this report are not to be construed as an official Department of the Army position unless so designated by other authorized documents. 


\section{Contents}

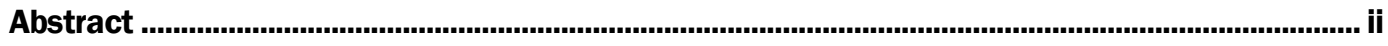

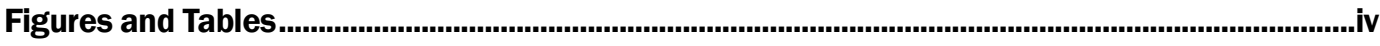

Preface ................................................................................................................................................vi

Unit Conversion Factors ..............................................................................................................................vii

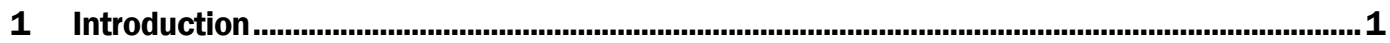

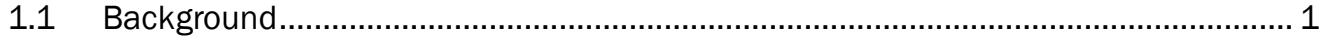

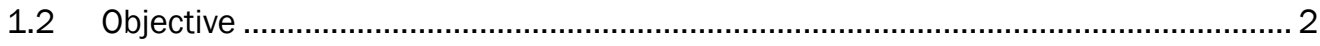

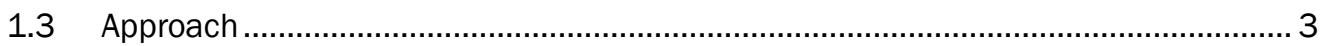

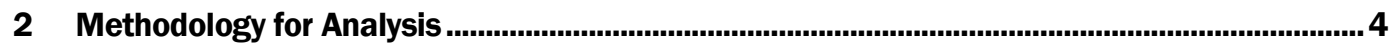

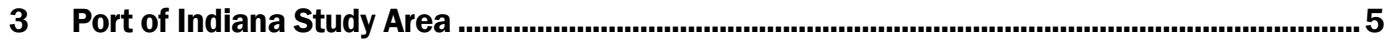

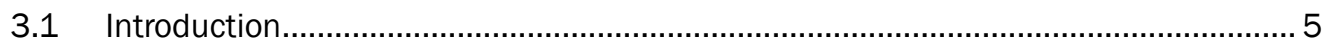

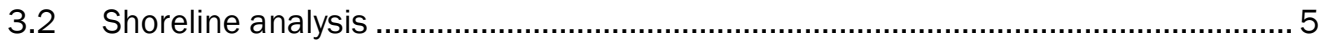

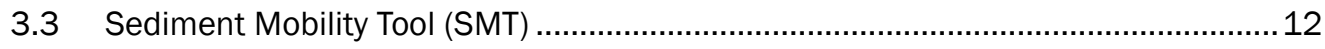

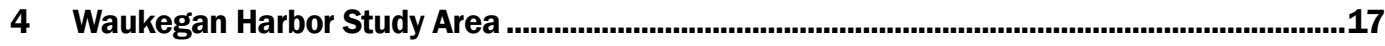

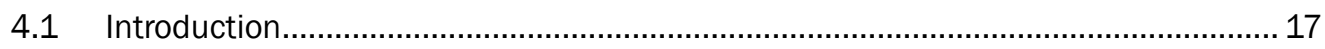

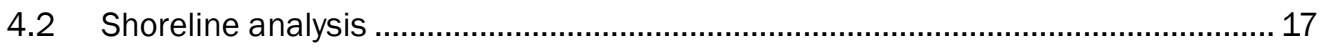

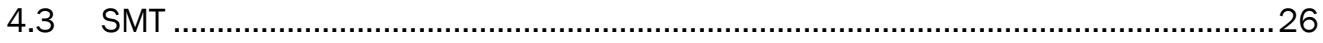

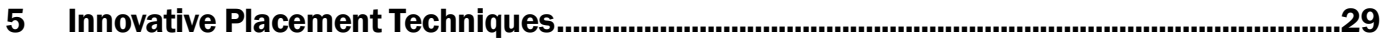

6 Conclusions..................................................................................................................................32

References ..........................................................................................................................................3

Report Documentation Page 


\section{Figures and Tables}

\section{Figures}

Figure 1. Port of Indiana study area with dredged material placement locations.

Figure 2. Shoreline change from the Port of Indiana to the U.S. Steel Landfill from 1969 to 2014.

Figure 3. Shoreline change from the Port of Indiana to the U.S. Steel Landfill from 1969 to 1973.

Figure 4. Shoreline change from the Port of Indiana to the U.S. Steel Landfill from 1973 to 1998.

Figure 5. Shoreline change from the Port of Indiana to the U.S. Steel Landfill from 1998 to 2005.

Figure 6. Shoreline change from the Port of Indiana to the U.S. Steel Landfill from 2005 to 2010 .

Figure 7. Shoreline change from the Port of Indiana to the U.S. Steel Landfill from 2010 to 2012 .

Figure 8. Shoreline change from the Port of Indiana to the U.S. Steel Landfill from 2012 to 2014 .

Figure 9. Histogram of a) the maximum bed shear stress using linear wave theory and b) the near-bottom velocity using nonlinear stream function wave theory for typical waves at a depth of $5.5 \mathrm{~m}(18 \mathrm{ft})$. The critical bed shear stress or near-bottom velocity for several grain sizes is noted with the respective vertical dashed lines. The measured median grain size is $d_{50}=0.15 \mathrm{~mm}$. $N$ is the number of waves from 1976 to 2014 in each shear stress bin, which is measured in increments of 10,000 . Values to the right of the vertical dashed lines mobilize the sediment.

Figure 10. Wave rose of the wave direction and zero moment wave height $\left(H_{m 0}\right)$ at the Port of Indiana nearshore placement site from a) typical waves from 1976 to 2014 and b) storms waves from 1960 to 1978 . The resultant wave direction vector during typical waves is $354^{\circ}$ from north and during storm waves is $343^{\circ}$ from north. Thus, the resultant vector is propagating from the north-northwest under both wave conditions.

Figure 11. Features and processes for the Waukegan Harbor study site.

Figure 12. Shoreline change from North Point Marina to Waukegan Harbor from 1939 to 2015 .

Figure 13. Shoreline change from North Point Marina to Waukegan Harbor from 1939 to 1946 .

Figure 14. Shoreline change from North Point Marina to Waukegan Harbor from 1946 to 1974

Figure 15. Shoreline change from North Point Marina to Waukegan Harbor from 1974 to 1988 .

Figure 16. Shoreline change from North Point Marina to Waukegan Harbor from 1988 to 2004

Figure 17. Shoreline change from North Point Marina to Waukegan Harbor from 2004 to 2007 .

Figure 18. Shoreline change from North Point Marina to Waukegan Harbor from 2007 to 2010 . 
Figure 19. Shoreline change from North Point Marina to Waukegan Harbor from 2010 to 2012

Figure 20. Shoreline change from North Point Marina to Waukegan Harbor from 2012 to 2015.

Figure 21. Wave rose of the wave direction and zero moment wave height $\left(H_{m 0}\right)$ at the Waukegan nearshore placement site from a) typical waves from 1976 to 2014 and b) storms waves from 1960 to 1978 . The resultant wave direction vector during typical waves is $76^{\circ}$ from north and during storm waves is $91^{\circ}$ from north. Thus the resultant vector is propagating from an easterly direction under both wave conditions.

Figure 22. Vilano Beach, Florida, shoreline change using the MHHW tidal datum between preconstruction and 4 months after nearshore berm construction. Note the positive shoreline change on the lee side of the nearshore berms.

\section{Tables}

Table 1. Port of Indiana harbor dredging history from 1985 to 2015.

Table 2. Lake Michigan water levels at Station 9087044 located at Calumet Harbor, IL, between 1969 and 2014

Table 3. Accretion or erosion values for the 45-year study of Port of Indiana, IN.

Table 4. Summary of the predicted sediment mobilization frequency and sediment

migration directions for various grain sizes under typical and storm wave conditions.

Table 5. Waukegan Harbor Dredging History..

Table 6. Lake Michigan water levels at Station 9087044. Located at Calumet Harbor, IL, between 1939 and 2015.

Table 7. Accretion or erosion values for the 79-year study of Waukegan Harbor, IL.

Table 8. Summary of the predicted sediment mobilization frequency and sediment migration directions for various grain sizes under typical and storm wave conditions. 


\section{Preface}

This study was conducted for Headquarters, U.S. Army Corps of Engineers (HQUSACE), Washington, DC, under the USACE Regional Sediment Management (RSM) Program, project entitled "Evaluation of Nearshore Placement in Southern Lake Michigan."

At the time of publication, Mr. Gregory W. Dreaper was Acting Chief, CEERD-HN-C, and Mr. Charles E. Wiggins was Acting Chief, CEERD-HN. Ms. Linda S. Lillycrop, CEERD-HN-C, was the USACE National RSM Program Manager. Mr. W. Jeff Lillycrop, CEERD-CHL, was the Engineer Research and Development (ERDC) Technical Director for the Civil Works and Navigation Research, Development, and Technology Transfer (RD\&T) portfolio. Mr. Jeffrey A. McKee was the HQUSACE Navigation Business Line Manager overseeing the RSM Program.

The Acting Director of ERDC-CHL was Mr. Jeffrey R. Eckstein, and Dr. Jackie S. Pettway was the Acting Deputy Director.

COL Bryan S. Green was the Commander of ERDC, and Dr. David W. Pittman was the Director. 


\section{Unit Conversion Factors}

\begin{tabular}{|c|c|c|}
\hline Multiply & By & To Obtain \\
\hline cubic meters & 1.30795 & cubic yards \\
\hline meters & 3.28084 & feet \\
\hline inches & 0.0254 & meters \\
\hline microns & $1.0 \mathrm{E}-06$ & meters \\
\hline miles (U.S. statute) & 1609.347 & meters \\
\hline kilometers & 0.621371 & miles \\
\hline
\end{tabular}




\section{Introduction}

Regional Sediment Management (RSM) is a systems-based approach to manage sediments and is implemented collaboratively with other federal, state, and local agencies. The objective of the U.S. Army Corps of Engineers (USACE) RSM program is to improve the management of sediments across multiple projects, manage sediments as a regional-scale resource, and implement adaptive management strategies that support sustainable navigation and dredging, flood and storm damage reduction, and environmental practices that increase operational efficiencies, the value of sediments, and social and environmental/ecosystem benefits, while reducing lifecycle costs. RSM is also a means to involve stakeholders to leverage resources, share technology and data, identify needs and opportunities, and develop solutions to improve the utilization and management of sediments.

Implementation of RSM develops a better understanding of the regional sediment transport processes through integration of regional data and application of tools that improve knowledge of the regional processes, provides a means to understand and share demands for sediment, and results in identifying and implementing adaptive management strategies to optimize use of sediments and streamline projects. The adaptive management strategies are developed and implemented through application of the best available science and engineering practices and use of policies which permit regional approaches. Benefits of this approach are improved partnerships with stakeholders, improved sediment utilization and project management on a regional scale, improved environmental stewardship, and reduced overall lifecycle costs (Lillycrop et al. 2011).

\subsection{Background}

The southern shoreline of Lake Michigan is highly developed, and the presence of harbor structures and shoreline armoring interrupts the natural littoral movement of sediment. Remaining undeveloped areas contain valuable natural resources and provide protection for residential structures. To support the shoreline management goals of the State of Illinois, the State of Indiana, the National Park Service, and local communities, the USACE regularly places sediment dredged from two 
federal harbors, Waukegan Harbor in Illinois and the Port of Indiana, which is also known as the Burns Waterway Harbor or the International Port of Indiana, in the nearshore area along reaches that are threatened by erosion and coastal storm damage. Dredged sediments are primarily coarse sand suitable for beach nourishment, and the material is placed in a designated nearshore area that is directly accessible by the dredging scows. While this method of beneficial use of dredged material costs less than placement directly on the beach or closer to the shoreline, the effectiveness of these nearshore placements for shoreline protection and littoral nourishment has not yet been evaluated. Despite ongoing nearshore placement activities, the shorelines along these reaches continue to erode.

Erosion of the beach west of the Port of Indiana near the town of Ogden Dunes occurs due to the interruption of littoral sediment transport near the harbor complex, which includes private bulkheads and federal breakwaters. Since 1986, USACE and the Northern Indiana Public Service Company (NIPSCO) have placed over 2,500,000 cubic meters (m3) $(3,370,000$ cubic yards [yd3]) of dredged sediment in the nearshore area of this reach as part of efforts to protect the rare and significant natural habitat and the shoreline residences within the Town of Ogden Dunes.

Illinois Beach State Park is the last remaining reach of natural shoreline in Illinois and provides habitat for several state and federally listed threatened and endangered species. Armoring of the updrift shores and perpendicular structures prevents littoral mobilization of sediment that would otherwise nourish the park shoreline. USACE, in partnership with the Illinois Department of Natural Resources, has placed approximately $483,000 \mathrm{~m}^{3}(632,000 \mathrm{yd} 3)$ of dredged sediment from 1999 to 2013 in the nearshore area to help protect this critical natural resource. To date, the State of Illinois has funded the incremental cost of placing material within the nearshore area at Illinois Beach State Park.

\subsection{Objective}

The objective of this study is to improve the understanding of shoreline response in southern Lake Michigan to current dredged sediment placement techniques. 


\subsection{Approach}

Historical aerial photographs of the Lake Michigan shoreline were investigated with a Geographic Information System (GIS)-based approach to assess shoreline change over time. The shoreline information was combined with historical dredging and placement records to better understand the shoreline erosion or accretion tendencies. Additionally, current nearshore placement practices were evaluated with the Sediment Mobility Tool (SMT) using wave hindcasts to estimate the frequency placed sediment will be mobilized and where that sediment is likely to go. Finally, innovative placement techniques applied at other sites were investigated to potentially improve the shoreline response to dredged sediment placed in the nearshore. 


\section{Methodology for Analysis}

The historical shoreline analysis methodology was the same for both areas of interest (AOI). For imagery prior to 1998, paper-based photography was acquired, scanned into a digital format, and using known ground control points each photograph was georeferenced to Zone 16 of the Universal Transverse Mercator (UTM) projection. In each AOI, shorelines for each year were digitized at a scale of 1:2400 from imagery that was resampled to the spatial resolution of the coarsest dataset. The water level of Lake Michigan fluctuates due to precipitation, evaporation, and wind (USACE LRC 1995). For these reasons, the date of acquisition for each image was used, in conjunction with data from the National Oceanic and Atmospheric Administration's (NOAA) Tides \& Currents database, to adjust shorelines based on water levels.

Lake Michigan water levels have been recorded at Station 9087044 located at Calumet Harbor, IL, since 1905 (NOAA 2013). The Lake Michigan water level increased at the highest rate ever recorded in 2013 and 2014 due to above-average spring runoff, persistent over-lake precipitation, belowaverage evaporation, and high inflow rates from Lake Superior through the St. Marys River (Gronewold et al. 2016). The distance each shoreline was adjusted horizontally was based on the slope of the shoreline and the lake level at the time of the photograph, with the low-water mark shoreline serving as the base off which all other shorelines were adjusted landward. The shoreline slope for each AOI was determined separately and is described in subsequent sections.

The final shoreline features were used to calculate the net shoreline movement (NSM) between each successive imagery period along with the beginning and end dates to get an NSM for the study range. The U.S. Geological Survey's (USGS) Digital Shoreline Analysis System (DSAS) tool was used to generate NSM statistics. The DSAS tool was created with the purpose of assessing shoreline change statistics (Thieler et al. 2008). It has been redesigned over the years, and for this study version 4.3 .4730 for ArcMap 10.3.1 was used. DSAS creates transects of a user-defined interval and length that originate from a baseline. These transects intersect each of the shorelines as close to perpendicular as possible. This study placed transects every $50 \mathrm{~m}(164 \mathrm{ft})$ and compiled NSM statistics for each of the study areas. 


\section{Port of Indiana Study Area}

\subsection{Introduction}

The Port of Indiana study area is a section of shoreline approximately 9 kilometers $(\mathrm{km})$ (6 miles) in length bounded on the east by the west jetty of the Burns Small Boat Harbor and on the west by the eastern bulkhead of the U.S. Steel landfill. The study area is shown in Figure 1 and includes the National Park Service's Portage Lakefront Pavilion, the Town of Ogden Dunes, and the shorelines of Marquette Park and Gary, IN. The net littoral sediment transport in the area is from east to west (USACE 1995). The DSAS tool was used to generate 185 transects placed $50 \mathrm{~m}(164 \mathrm{ft})$ apart. Each transect provides statistics for the shoreline change between each of the image dates.

\subsection{Shoreline analysis}

Aerial imagery was located for this site from 1969 to 2014. Photography of the Port of Indiana study area from 1969 and 1973 was georeferenced to UTM Zone 16. Orthoimagery from the USGS Western Mapping Center was acquired for 1998. Imagery from the U.S. Department of Agriculture (USDA) Farm Service Agency's (FSA) National Agricultural Imagery Program (NAIP) was used for the years 2005, 2010, 2012, and 2014. All imagery was downloaded in the UTM Zone 16 projection, and with the exception of the 2005 imagery, that had a spatial resolution of $2 \mathrm{~m}(7 \mathrm{ft})$;

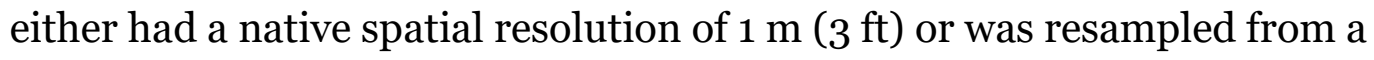
higher spatial resolution to $1 \mathrm{~m}$ ( $3 \mathrm{ft}$ ). The Port of Indiana study area is shown in Figure 1. 
Figure 1. Port of Indiana study area with dredged material placement locations.

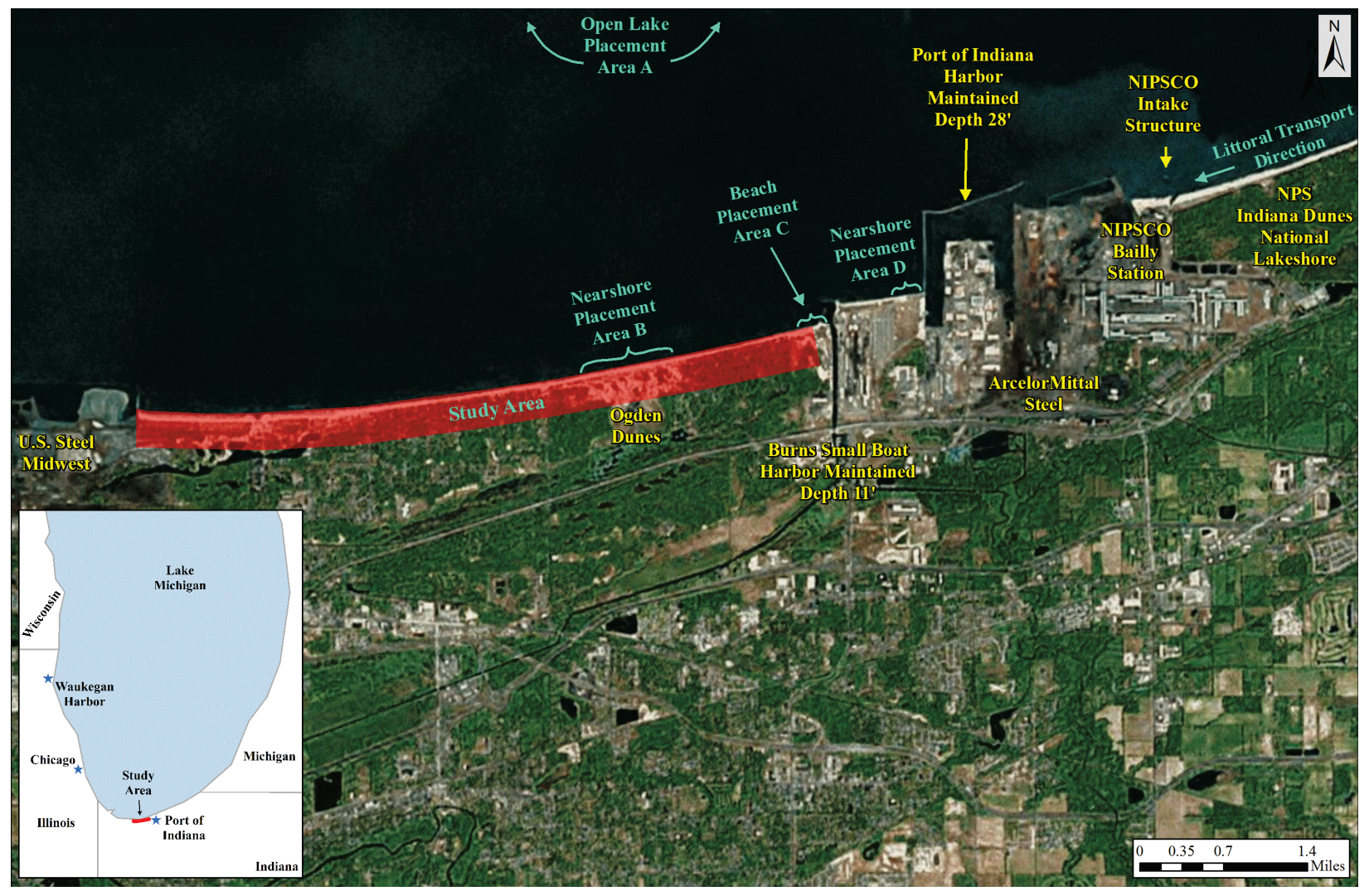

Dredging records between 1996 and 2015 were located for the Port of Indiana Harbor, the Burns Small Boat Harbor, and the NIPSCO water intake area that was dredged by both NIPSCO and USACE over the nearly 35-year period. These values, along with the material placement locations, are listed in Table 1.

Table 1. Port of Indiana harbor dredging history from 1985 to 2015.

\begin{tabular}{|l|c|c|c|l|}
\hline Project & Year & Quantity $\mathrm{m}^{3}$ & ${\text { Quantity } \mathbf{y d}^{\mathbf{3}}}$ & Placement Location \\
\hline \multirow{4}{*}{$\begin{array}{l}\text { Port of } \\
\text { Indiana } \\
\text { Harbor }\end{array}$} & 1996 & 203,000 & 266,000 & Open lake placement - Area A \\
\cline { 2 - 5 } & 2007 & 174,000 & 228,000 & Open lake placement - Area A \\
\cline { 2 - 5 } & 2008 & 42,000 & 55,000 & Open lake placement - Area A \\
\cline { 2 - 5 } & 2013 & 54,000 & 70,000 & Nearshore placement - Area D \\
\cline { 2 - 5 } & 2014 & 50,000 & 65,000 & Nearshore placement - Area B \\
\cline { 2 - 5 } & 2014 & 54,000 & 70,000 & Nearshore placement - Area B \\
\cline { 2 - 6 } & 2016 & 52,000 & 55,000 & Nearshore placement - Area B \\
\hline
\end{tabular}




\begin{tabular}{|c|c|c|c|c|}
\hline Project & Year & Quantity $\mathrm{m}^{3}$ & Quantity yd ${ }^{3}$ & Placement Location \\
\hline \multirow{4}{*}{$\begin{array}{l}\text { Burns } \\
\text { Small Boat } \\
\text { Harbor }\end{array}$} & 1985 & 46,000 & 59,000 & Beach placement - Area C \\
\hline & 1986 & 51,000 & 67,000 & Beach placement - Area C \\
\hline & 2000 & 109,000 & 143,000 & Beach placement - Area C \\
\hline & 2009 & 61,000 & 80,000 & Nearshore placement - Area B \\
\hline \multirow{9}{*}{$\begin{array}{l}\text { NIPSCO } \\
\text { Intake } \\
\text { (NIPSCO } \\
\text { Dredged) }\end{array}$} & 1980 & 210,000 & 275,000 & Unspecified open lake placement \\
\hline & 1982 & 167,000 & 218,000 & Shoreline at BGS \\
\hline & 1986 & 245,000 & 320,000 & Nearshore placement - Area B * \\
\hline & 1989 & 220,000 & 288,000 & Nearshore placement - Area B * \\
\hline & 1992 & 160,000 & 209,000 & Nearshore placement - Area B * \\
\hline & 1995 & 90,000 & 118,000 & Nearshore placement - Area B * \\
\hline & 1997 & 112,000 & 146,000 & Nearshore placement - Area B * \\
\hline & 1999 & 126,000 & 165,000 & Nearshore placement - Area B * \\
\hline & 2016 & 50,000 & 65,000 & Nearshore placement - Area B \\
\hline \multirow{4}{*}{$\begin{array}{l}\text { NIPSCO } \\
\text { Intake } \\
\text { (USACE } \\
\text { Dredged) }\end{array}$} & 2006 & 23,000 & 30,000 & Nearshore placement - Area B \\
\hline & 2007 & 174,000 & 228,000 & Nearshore placement - Area B \\
\hline & 2008 & 80,000 & 105,000 & Nearshore placement - Area B \\
\hline & 2009 & 84,000 & 110,000 & Nearshore placement - Area B \\
\hline
\end{tabular}

* NIPSCO 1986 to 1999 dredges placed 75\% of the material nearshore at Ogden Dunes and 25\% nearshore at Beverly Shores.

The shoreline features were adjusted for Lake Michigan water levels based on the photography date. Shoreline slope is necessary to adjust the horizontal shoreline due to variable lake levels. A light detection and ranging (lidar)-based bare earth digital elevation model (DEM) with a $2 \mathrm{~m}$ (7 ft) spatial resolution was downloaded from the USDA Geospatial Data Gateway (https://gdg.sc.egov.usda.gov/GDGOrder.aspx). A percent slope matrix was generated from the DEM, and those cells that intersected each of the 185 transects within the study area were selected. The shoreline slope ranged from $9 \%$ to $13 \%$. In a 1990 study for NIPSCO, two coastal profile sites were studied over a period of 20 years, ending in 1985 . Both of these sites were on the east side of the Port of Indiana jetty, within a quarter mile of that feature. While from year to year the nearshore and beach slopes changed, the beach slope remained in the range of $9 \%$ to $13 \%$ at each of the sampling sites and dates (Wood 1990). In a separate study monitoring shoreline change to the west of the Burns Small Boat Harbor, a coastal profile found the nearshore slope to be 11.2\% (USACE 1995). Finally, in a 2008 study the beach slope near the Port of Indiana was found to be $11 \%$ 
(USACE 2008). Thus, combining the results of these three studies with the DEM-based shoreline slope range of $9 \%$ to $13 \%$, a median shoreline slope of $11 \%$ was chosen for this study.

The low-water mark for this 45 year period occurred on 30 September 2005 , with a reading of $175.93 \mathrm{~m}$. (577.21 ft). This value was considered the base shoreline, and the digitized shorelines from all other years were adjusted accordingly. The lake level for each photography date, the change in feet from the low-water date of 30 September 2005, and the relative adjustment of the shoreline landward are listed in Table 2.

Table 2. Lake Michigan water levels at Station 9087044 located at Calumet Harbor, IL, between 1969 and 2014.

\begin{tabular}{|c|c|c|c|}
\hline Image Date & Lake Level $(\mathrm{m})$ & Change from 2005 $(\mathrm{m})$ & Shoreline Adjustment $(\mathrm{m})$ \\
\hline $6 / 28 / 1969$ & 176.83 & 0.89 & 8.12 \\
\hline $12 / 2 / 1973$ & 176.93 & 3.28 & 9.09 \\
\hline $4 / 11 / 1998$ & 176.91 & 1.00 & 8.84 \\
\hline $9 / 30 / 2005$ & 175.93 & 0.0 & 0.00 \\
\hline $8 / 6 / 2010$ & 176.27 & 0.34 & 3.05 \\
\hline $6 / 6 / 2012$ & 176.13 & 0.20 & 1.83 \\
\hline $10 / 26 / 2014$ & 176.56 & 0.62 & 5.65 \\
\hline
\end{tabular}

Shoreline erosion and accretion were analyzed with the adjusted shorelines. As shown in Figure 2, the eastern third of the study area is characterized by erosion, likely as a result of the Port of Indiana and Burns Small Boat Harbor breakwaters, which cause sediment to accumulate updrift and erode downdrift. Since the construction of the Port of Indiana in 1968, the shoreline between the harbor features and the east end of Ogden Dunes had eroded more than $100 \mathrm{~m}$ (328 ft) by 1994 (Shabica and Pranschke 1994). While immediately updrift of the harbor, sediment accumulation around the NIPSCO Bailly Power Plant has warranted dredging every third year (USACE 1995). However, more frequent dredging is now required as $64,000 \mathrm{~m}^{3}\left(84,000 \mathrm{yd}^{3}\right)$ of sediment per year is bypassing the Arcelor Mittal bulkhead and entering the harbor (Morang et al. 2015). For the 45-year period from 1969 to 2014, the shoreline from the west breakwater of the Burns Small Boat Harbor to the east end of Ogden Dunes eroded an average of $40 \mathrm{~m}(131 \mathrm{ft})$. The $500 \mathrm{~m}(1,640 \mathrm{ft})$ stretch west of this area, including the eastern half of Ogden Dunes,

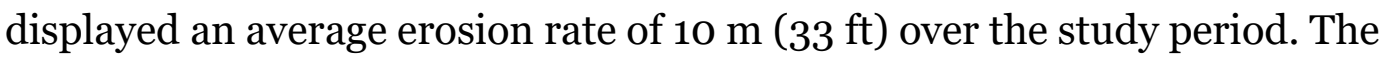


western $3.5 \mathrm{~km}$ (2 miles) of the shoreline, approximately from Marquette Park in Gary, IN, to the east jetty of the U.S. Steel landfill, had significant accretion, with an average shoreline accretion of $107 \mathrm{~m}(351 \mathrm{ft})$. The remaining $5 \mathrm{~km}$ (3 miles) in the center of the study area displayed modest levels of accretion.

Figure 2. Shoreline change from the Port of Indiana to the U.S. Steel Landfill from 1969 to 2014.

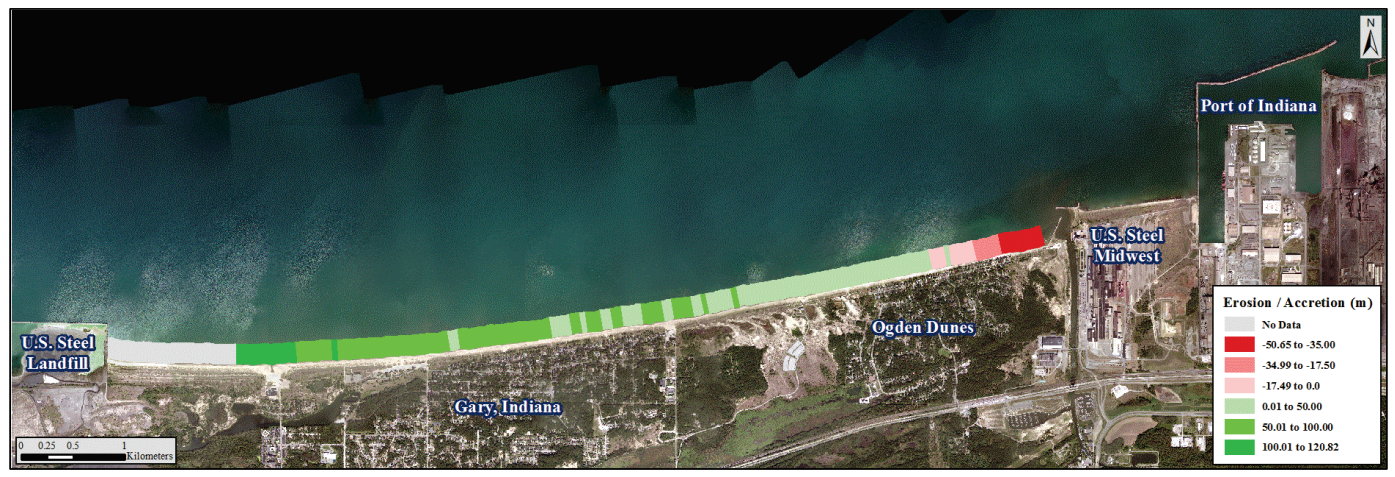

As shown in Figure 3, from 1969 to 1973 there was erosion occurring from the west jetty of the Burns Small Boat Harbor and the area $1 \mathrm{~km}$ (o.62 mile) to the west. Between 1973 and 1998, as shown in Figure 4, there was even more significant erosion in this area. From 1969 to 1998 the water level of Lake Michigan was at its highest point for the study period, with the highest water levels of the century occurring in the mid1980 s. These water levels, combined with the number of storms with a northerly component likely contributed to the increased erosion (USACE 1995). Storms with a northerly component result in more damage due to Lake Michigan's lengthy fetch allowing wind-induced waves to fully develop. This erosion could have been significantly worse, but during the same timeframe $872,000 \mathrm{~m}^{3}\left(1,140,000 \mathrm{yd}^{3}\right)$ of dredged material was placed in the nearshore or directly on the beach west of the Burns Small Boat Harbor jetty, which added sediment to the littoral system. 
Figure 3. Shoreline change from the Port of Indiana to the U.S. Steel Landfill from 1969 to 1973 .

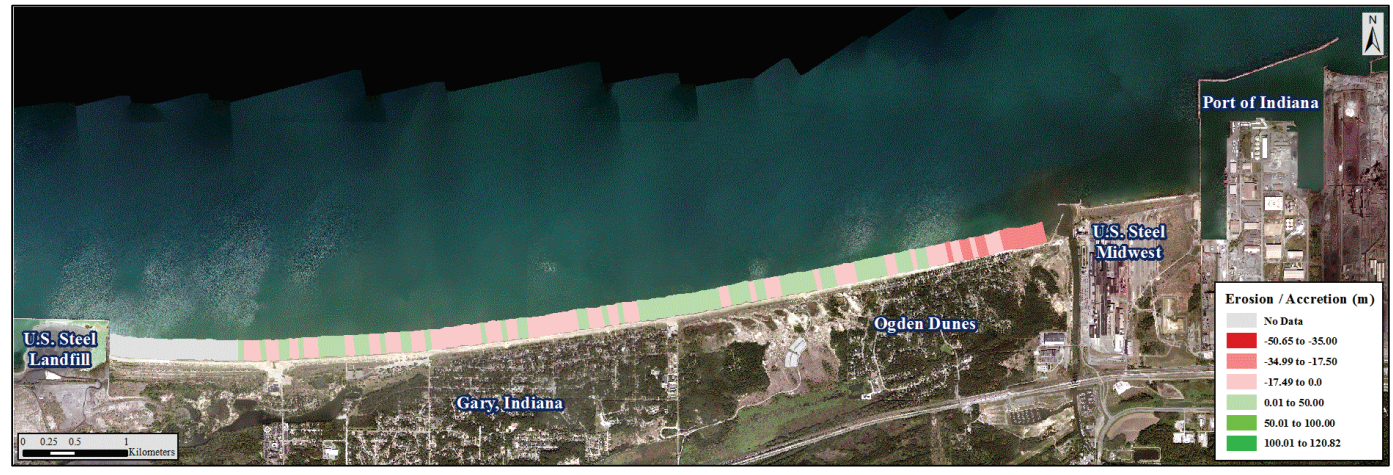

Figure 4. Shoreline change from the Port of Indiana to the U.S. Steel Landfill from 1973 to 1998.

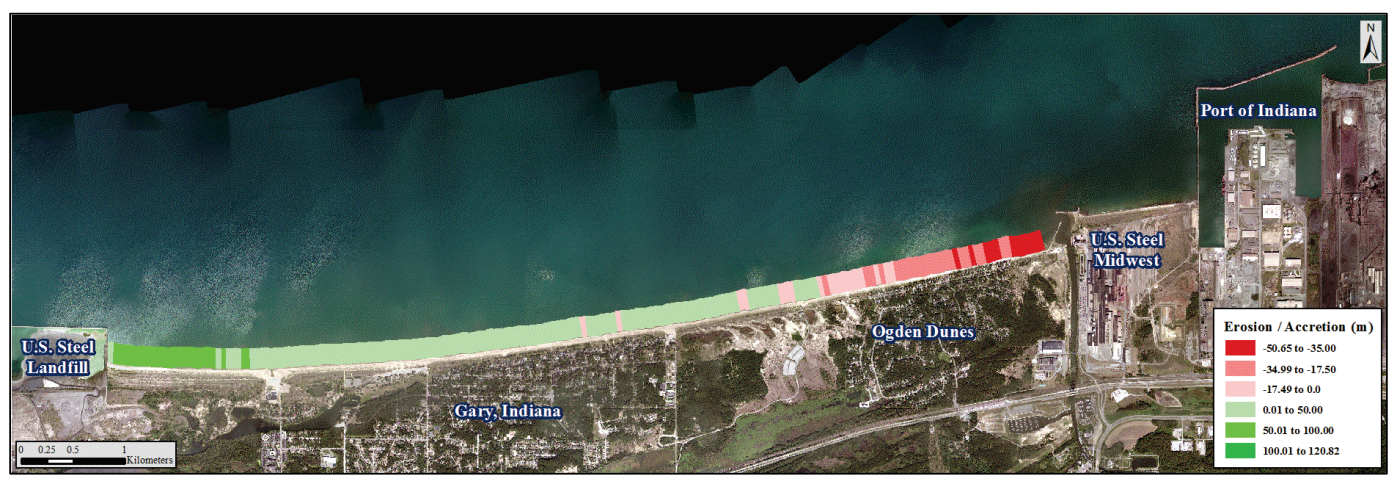

During the 1998 to 2005 timeframe, a total of $235,000 \mathrm{~m}^{3}$ (308,000 yd3) of material was placed in the nearshore or directly on the beach, all of which was placed in 1999 and 2000. The effects of this material that was consistently placed into the littoral system at the critical erosion area is reflected in the 1998 to 2005 period data, as shown in Figure 5.

Figure 5. Shoreline change from the Port of Indiana to the U.S. Steel Landfill from 1998 to 2005.

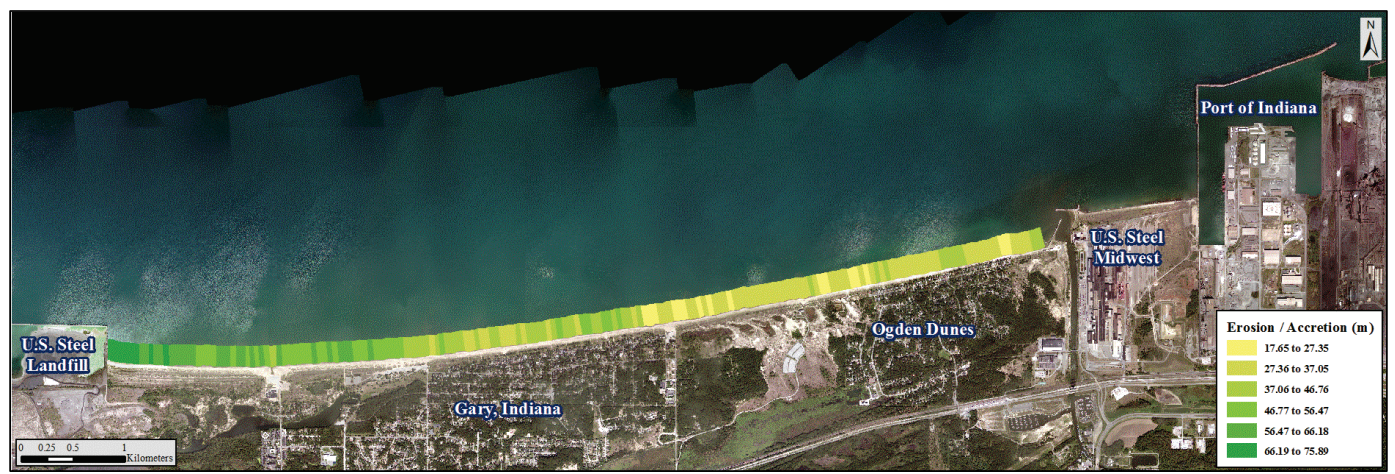


During this 8-year period, even the most erosion-prone areas accreted nearly $18 \mathrm{~m}$ ( $59 \mathrm{ft}$ ), with the natural accretion areas moving the shoreline

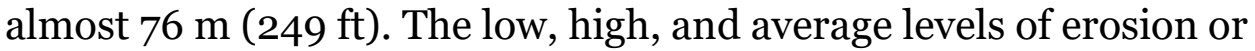
accretion by successive years in the study period as well as for the entire study period are listed in Table 3 .

Table 3. Accretion or erosion values for the 45-year study of Port of Indiana, IN.

\begin{tabular}{|c|c|c|c|}
\hline Date Range & Range Low $(\mathrm{m})$ & Range High $(\mathrm{m})$ & Range Average $(\mathrm{m})$ \\
\hline 1969 to 1973 & -29.79 & 12.73 & -2.57 \\
\hline 1973 to 1998 & -66.55 & 78.98 & 10.88 \\
\hline 1998 to 2005 & 17.65 & 75.89 & 42.34 \\
\hline 2005 to 2010 & -14.28 & 32.90 & 6.83 \\
\hline 2010 to 2012 & -14.74 & 16.68 & 2.09 \\
\hline 2012 to 2014 & -21.67 & 14.22 & -0.92 \\
\hline 1969 to 2014 & -50.65 & 120.82 & 45.37 \\
\hline
\end{tabular}

Between 2005 and 2012, the water level of Lake Michigan was approximately $3 \mathrm{ft}$ lower than the high-water period from 1969 to 1998. The lower water level reduces the amount of shoreline and bluff erosion. The degree of erosion and accretion across the study area for 2005 to 2012 was less dramatic than during the times of higher water. From 2005 to 2010, as shown in Figure 6, slight erosion was measured on the eastern end of the study area, and slight accretion was measured in the central and western end of the study area. The shoreline changes from 2010 to 2014, shown in Figures 7 and 8, have small sections of minor accretion and minor erosion throughout the study area.

Figure 6. Shoreline change from the Port of Indiana to the U.S. Steel Landfill from 2005 to 2010.

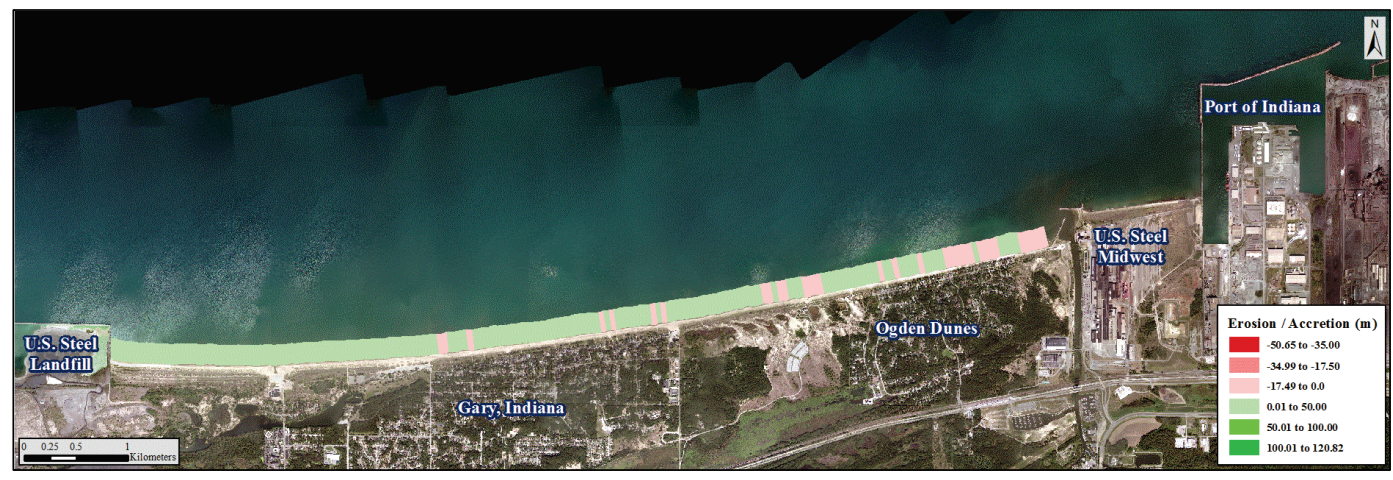


Figure 7. Shoreline change from the Port of Indiana to the U.S. Steel Landfill from 2010 to 2012

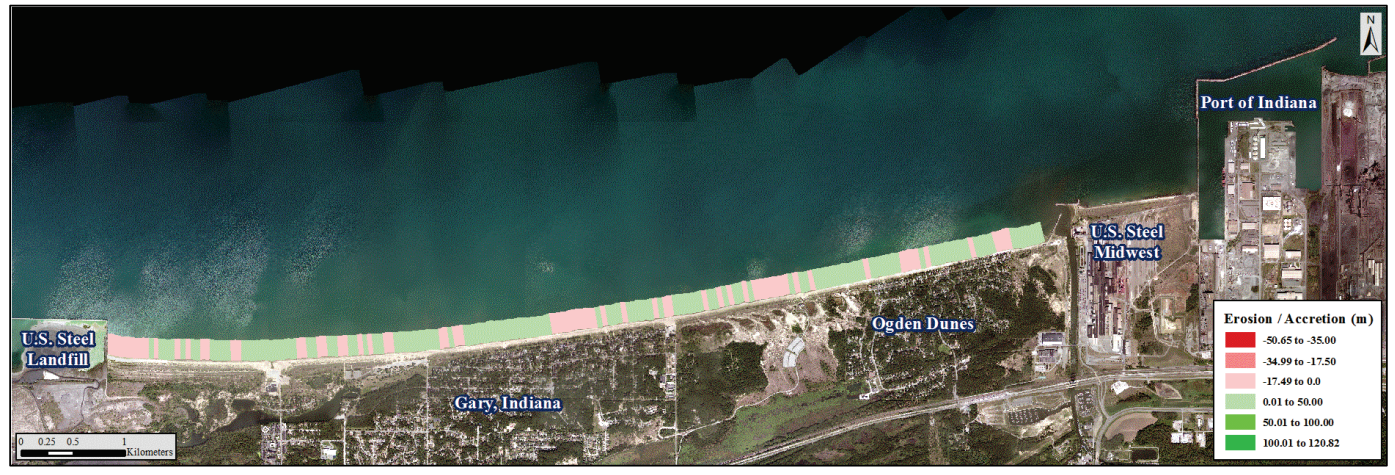

Figure 8. Shoreline change from the Port of Indiana to the U.S. Steel Landfill from 2012 to 2014.

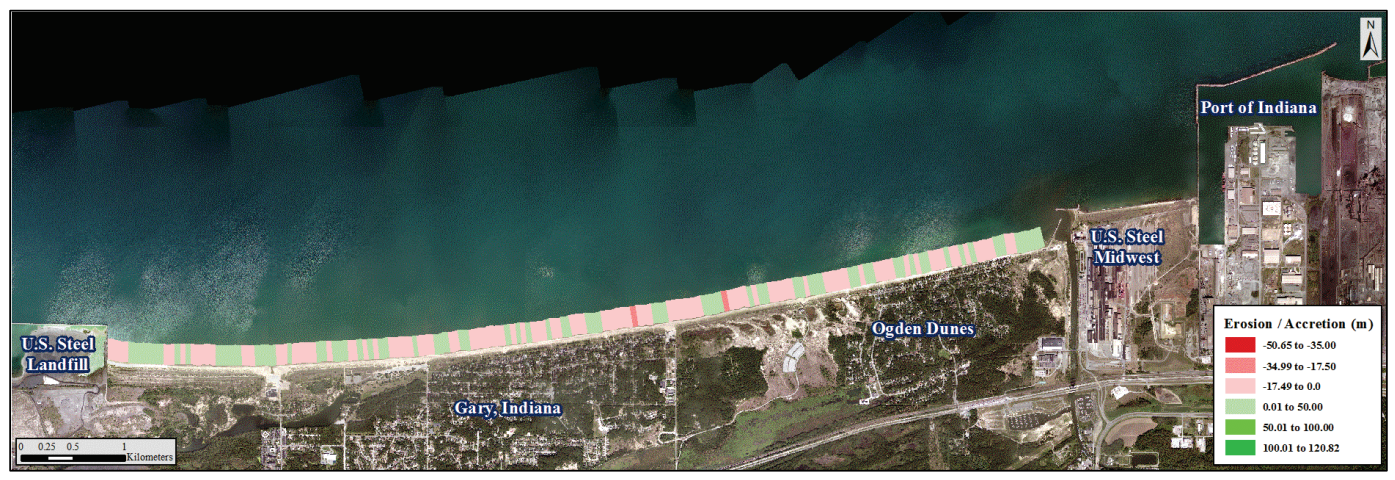

\subsection{Sediment Mobility Tool (SMT)}

The SMT is a scoping-level numerical model that is designed to assist planners and engineers to site nearshore placement areas for dredged material by calculating the frequency that sediment of particular grain sizes will be mobilized and where it is likely to go. Two methods are applied to estimate the frequency of sediment mobility for a selected location: water depth and sediment grain size of the material to be placed. McFall et al. (2016) describe the equations used in SMT in detail, but a brief summary of the methods will be discussed here. The first method analyzes the bed shear stress from local wave and current conditions and compares it with the critical thresholds for various median grain size diameters. Assuming wave steepness (wave steepness equals wave height/wave length) is small, the first method employs linear wave theory to calculate the near-bed wave orbital velocity and the resulting bed shear stress. The second method analyzes the near-bed velocity and compares the critical near-bed velocity to locally generated velocities. The second method uses nonlinear stream function wave theory to calculate the near- 
bed wave orbital velocity, which generally produces larger velocities than linear wave theory. By using both methods, a range of mobility is calculated.

Wave hindcast data from the USACE Wave Information Studies (WIS) from 1976 to 2014 were transformed to the nearshore placement location using Snell's Law and the conservation of energy flux. Additionally, WIS wave hindcast and nine water level gauges in Lake Michigan were used to assess storm surge conditions from 1960 to 1978 . These waves were hindcast using barometric and water level conditions for those times. Wave hindcasts from WIS Station 94001, approximately $6 \mathrm{~km}$ (4 miles) offshore, were used for the Port of Indiana study site, and a mild longshore current $1 \mathrm{~m}(3 \mathrm{ft})$ above the bed was assumed to be $0.05 \mathrm{~m} / \mathrm{s}(0.16 \mathrm{ft} / \mathrm{s})$. A

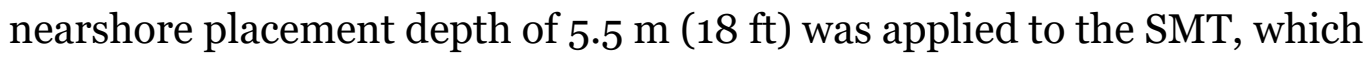
is the maximum depth of the existing nearshore placement area permit. The median grain size, d5o, for the dredged sediment is $0.15 \mathrm{~mm}$.

The histograms created to estimate the frequency of sediment mobilization for the typical waves from 1976 to 2014 are shown in Figure 9. The critical thresholds to initiate sediment movement are noted with the colored, vertical dashed lines. The legend using linear wave theory (Figure 9a) shows the various median grain sizes $\left(d_{50}\right)$, critical shear stress $\left(\tau_{c r}\right)$, frequency of mobility $\left(\mathrm{f}_{M}\right)$, and the mean mobility score, $\mathrm{M}$, which is given as:

$$
M=\overline{\left(\frac{\tau_{\max }-\tau_{c r}}{\tau_{c r}}\right)}
$$

The histogram legend using nonlinear stream function wave theory (Figure $9 \mathrm{~b}$ ) shows the various grain sizes, critical near-bottom velocity $\left(u_{c r}\right)$, frequency of mobility $\left(\mathrm{f}_{M}\right)$, and the mean mobility score for the near-bottom velocity which is given as:

$$
M_{u}=\overline{\left(\frac{u_{\max }-u_{c r}}{u_{c r}}\right)}
$$


Figure 9. Histogram of a) the maximum bed shear stress using linear wave theory and b) the near-bottom velocity using nonlinear stream function wave theory for typical waves at a depth

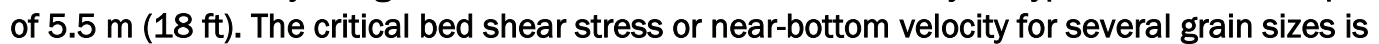
noted with the respective vertical dashed lines. The measured median grain size is $d_{50}=0.15 \mathrm{~mm} . N$ is the number of waves from 1976 to 2014 in each shear stress bin, which is measured in increments of 10,000 . Values to the right of the vertical dashed lines mobilize the sediment.

a)

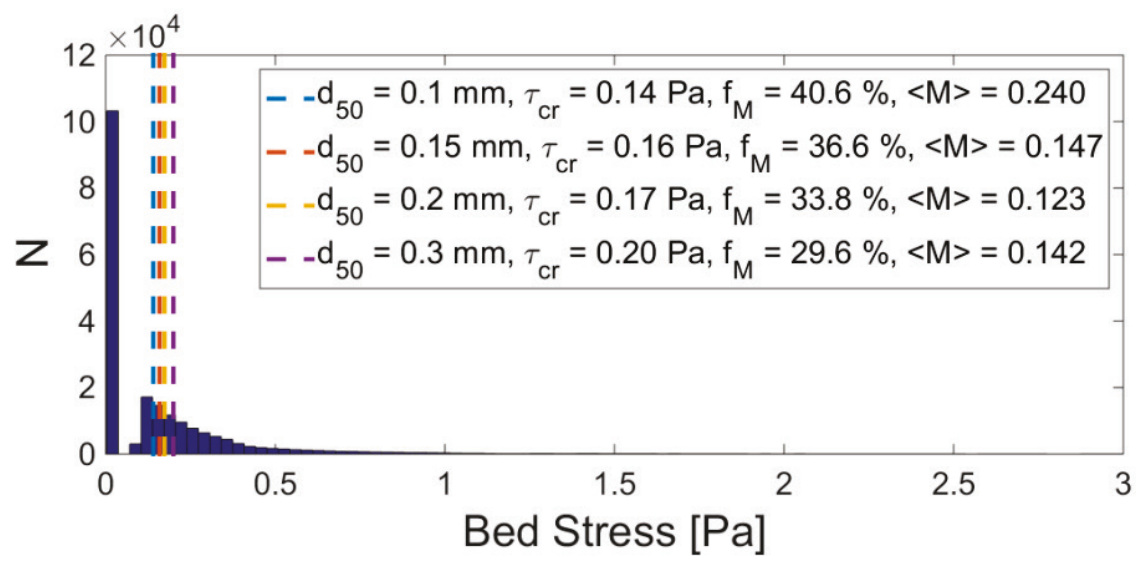

b)

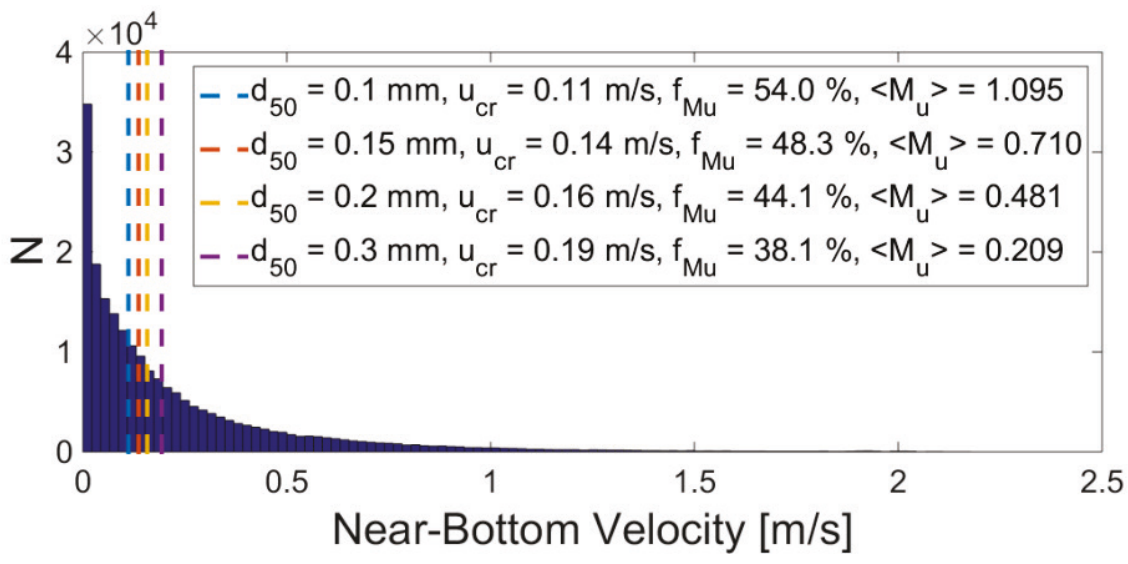

The same methods that were applied to the typical wave conditions were applied to the storm event wave conditions to compare the frequency of sediment mobilization. Table 4 shows the frequency of sediment mobilization for several grain sizes using both linear and nonlinear wave theories on typical and storm wave conditions at the Port of Indiana nearshore placement site.

Larson and Kraus (1992) hypothesized that artificial nearshore berm behavior should be similar to natural sand bars and studied the onshore and offshore migration of the offshore bar in Duck, NC, from 1981 to 1989. The dimensionless Dean number is generally used to determine bar migration and is given as: 


$$
D=\frac{H_{0}}{\omega T}
$$

where $H_{0}$ is the offshore wave height, $\omega$ is the sediment fall speed, and $T$ is the wave period. Dean Number, D, values greater than 7.2 were found to induce erosive, offshore bar migration, and values less than 7.2 resulted in accretionary, onshore bar migration.

The sediment fall speed is dependent on the grain size diameter and was calculated with the equations derived by Hallermeier (1981). The Dean Number is calculated for each wave record with each noted sediment grain diameter, and the predicted sediment migration results are listed in Table 4. The finer sands are generally transported offshore during storm waves while the coarser sands are transported towards shore.

Table 4. Summary of the predicted sediment mobilization frequency and sediment migration directions for various grain sizes under typical and storm wave conditions.

\begin{tabular}{|c|c|c|c|c|}
\hline \multirow{2}{*}{$\mathbf{d}_{50}(\mathrm{~mm})$} & \multicolumn{2}{|c|}{ Typical Waves } & \multicolumn{2}{c|}{ Storm Events } \\
\cline { 2 - 5 } & $\begin{array}{c}\text { Frequency of } \\
\text { Mobilization }\end{array}$ & $\begin{array}{c}\text { Sediment } \\
\text { Migration }\end{array}$ & $\begin{array}{c}\text { Frequency of } \\
\text { Mobilization }\end{array}$ & $\begin{array}{c}\text { Sediment } \\
\text { Migration }\end{array}$ \\
\hline 0.1 & $41 \%-54 \%$ & $68 \%$ Onshore & $79 \%-87 \%$ & $51 \%$ Offshore \\
\hline 0.15 & $37 \%-48 \%$ & $91 \%$ Onshore & $76 \%-84 \%$ & $72 \%$ Offshore \\
\hline 0.2 & $34 \%-44 \%$ & $97 \%$ Onshore & $73 \%-81 \%$ & $85 \%$ Onshore \\
\hline 0.3 & $30 \%-38 \%$ & $99 \%$ Onshore & $68 \%-76 \%$ & $96 \%$ Onshore \\
\hline
\end{tabular}

In Table 4 , the $d_{5 o}$ of $0.15 \mathrm{~mm}$ was predominantly accretionary under typical wave conditions and erosive under storm wave conditions. This could indicate that the sediment placed in the nearshore would move shoreward under typical waves and could be considered "sacrificial" sediment to erode during storms, thus adding some protection to the beach. It should be noted that beaches and sand bars tend to show accretionary properties after storms, so sediment eroded during storms is likely to stay in the littoral system. Figure 10 shows a wave rose of the wave direction and wave height to estimate the dominant axis of waveinduced sediment transport. 
Figure 10. Wave rose of the wave direction and zero moment wave height $\left(H_{m 0}\right)$ at the Port of Indiana nearshore placement site from a) typical waves from 1976 to 2014 and b) storms waves from 1960 to 1978 . The resultant wave direction vector during typical waves is $354^{\circ}$ from north and during storm waves is $343^{\circ}$ from north. Thus, the resultant vector is propagating from the north-northwest under both wave conditions.

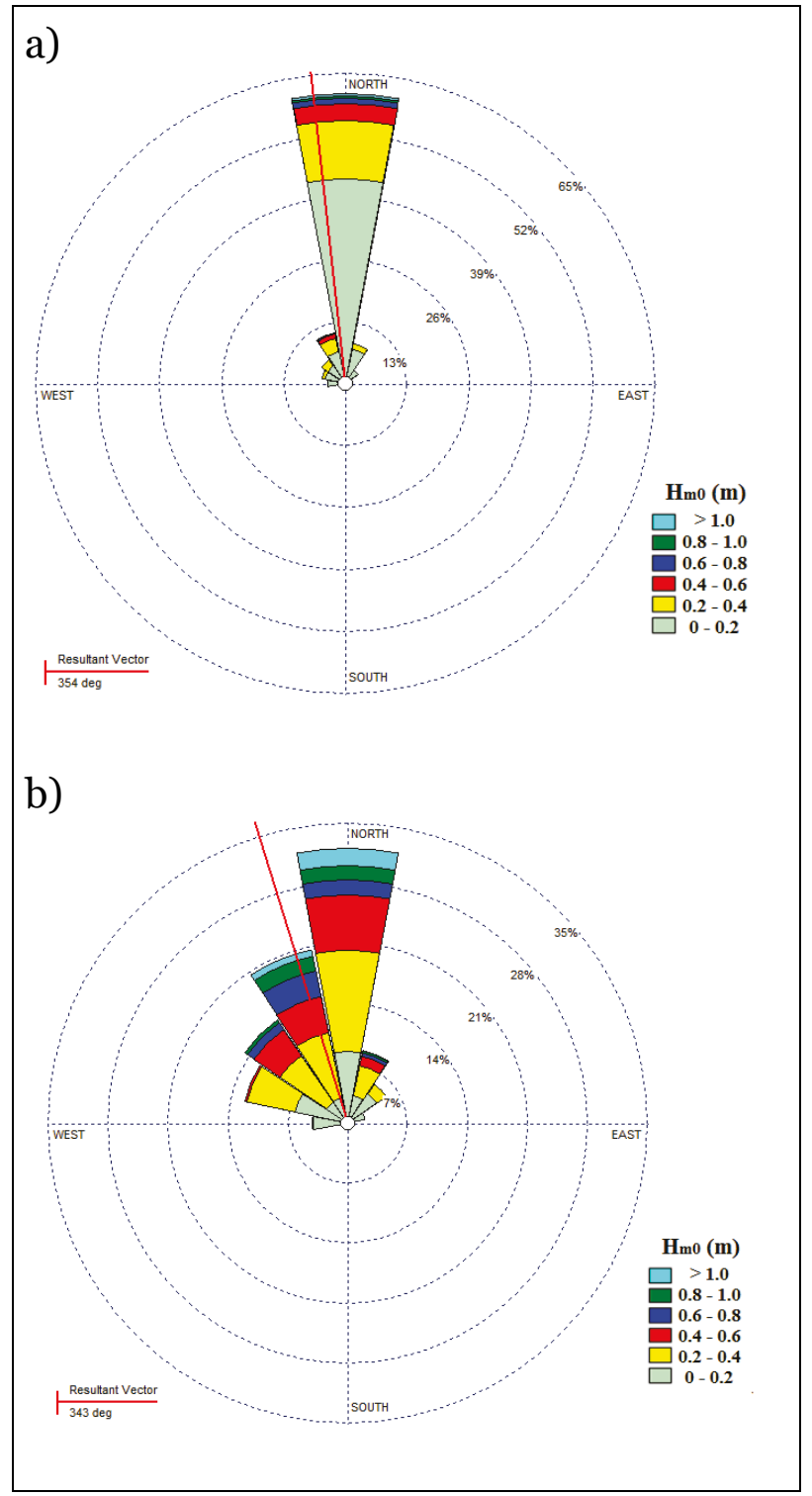




\section{Waukegan Harbor Study Area}

\subsection{Introduction}

The Waukegan Harbor study area is a section of shoreline approximately $11 \mathrm{~km}$ (7 miles) in length and is bounded on the north by the North Point Marina and on the south by the breakwater of the Midwest Generation Power Plant. The area includes both the north and south units of the Illinois Beach State Park, which are divided by the Zion Nuclear Power Station. The sands of the beach within the state park are part of the Zion beach-plain that has been gradually migrating south through littoral processes over the last several thousand years (Chrzastowski et al. 1994). Armoring of the updrift shores prevents littoral mobilization of sands that would otherwise nourish the park and Waukegan Harbor area shorelines.

\subsection{Shoreline analysis}

The DSAS was used to generate 225 transects $50 \mathrm{~m}(164 \mathrm{ft})$ apart. Each transect provides statistics for the shoreline change between each successive image date as well as the change between 1939 and 2015, which were the start and end years of the study. Photography of the Waukegan Harbor study area from 1939, 1946, and 1974 was acquired and georeferenced to UTM Zone 16. Orthoimagery from the USDA Farm Service Agency's (FSA) National Agricultural Imagery Program (NAIP) was used for the years 2004, 2007, 2010, 2012, and 2015. All imagery was downloaded in the UTM Zone 16 projection and either had a spatial resolution of, or was resampled to $2 \mathrm{~m}$ ( $7 \mathrm{ft}$ ). The 1988 shoreline uses 1974 and 1975 field data from an unpublished Illinois State Geological Survey atlas ${ }^{1}$. For each year, the shoreline of Lake Michigan was digitized at a scale of 1:2400. The Waukegan Harbor, Illinois study area is shown in Figure 11, and the placed dredged sediment in the study area is listed in Table 5.

\footnotetext{
1 Morang, A., M. J. Chrzastowski, D. F. Bucaro and J. A. Wethington. In preparation. Sediment Budget for the North Illinois Shore from the Wisconsin Border to Wilmette Harbor. ERDC/CHL Technical Report. Vicksburg, MS: U.S. Army Engineer Research and Development Center.
} 
Figure 11. Features and processes for the Waukegan Harbor study site.

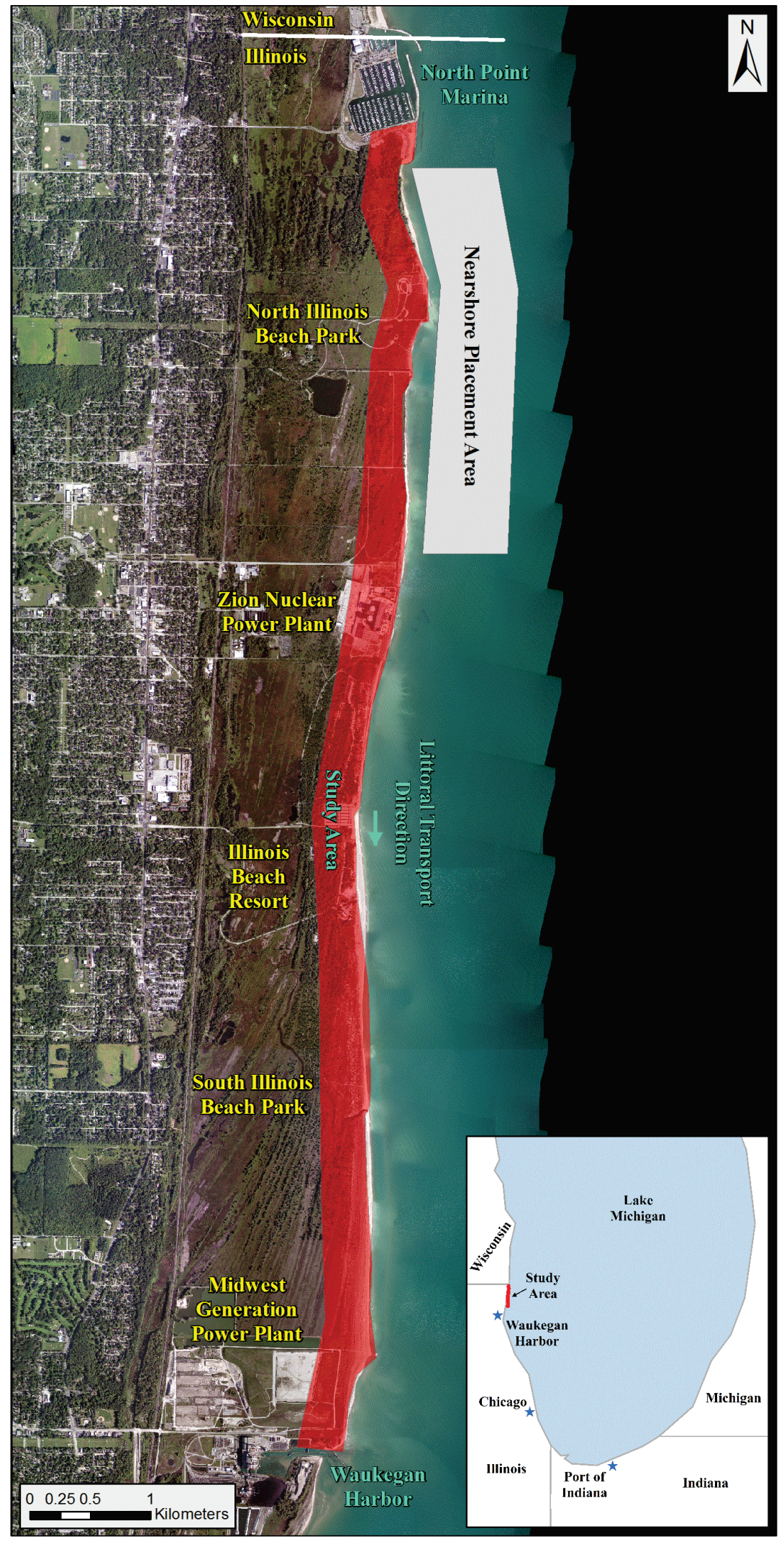


Table 5. Waukegan Harbor dredging history.

\begin{tabular}{|c|c|c|l|}
\hline Year & Quantity $\left(\mathrm{m}^{3}\right)$ & Quantity $\left(\mathbf{y d}^{\mathbf{3}}\right)$ & Placement Location \\
\hline 1999 & 47,000 & 62,000 & Nearshore placement area \\
\hline 2000 & 43,000 & 56,000 & Nearshore placement area \\
\hline 2001 & 43,000 & 56,000 & Nearshore placement area \\
\hline 2002 & 38,000 & 49,000 & Nearshore placement area \\
\hline 2005 & 23,000 & 30,000 & Nearshore placement area and south \\
\hline 2008 & 55,000 & 72,000 & Nearshore placement area and south \\
\hline 2009 & 52,000 & 68,000 & Nearshore placement area and south \\
\hline 2010 & 47,000 & 61,000 & Nearshore placement area and south \\
\hline 2012 & 80,000 & 105,000 & Nearshore placement area and south \\
\hline 2013 & 56,000 & 73,000 & Nearshore placement area and south \\
\hline
\end{tabular}

Shoreline features were adjusted for Lake Michigan water levels based on the image date. The slope used for this calculation was derived from both data analysis and previous research. A lidar-based, bare-earth DEM with a $2 \mathrm{~m}$ (7 ft) spatial resolution was downloaded from the USDA Geospatial Data Gateway. A percent slope matrix was generated from the DEM, and the cells that intersected each of the 229 transects within the study area were selected. For all transects, the average slope value of the selected cells was $9.1 \%$. In a recent sediment transport report covering the same study area, it was found that between the Midwest Generation Power Plant and the north jetty for Waukegan Harbor the beach slope was $10 \%{ }^{1}$, which is the value used to calculate horizontal shoreline adjustment based on water levels. The low-water mark for the 79-year study was $176.173 \mathrm{~m}$. (577.99 ft) on 7 July 2007. Using the 2007 shoreline as a base, all other shoreline features were adjusted, as shown in Table 6.

\footnotetext{
${ }^{1}$ Morang, A., M. J. Chrzastowski, D. F. Bucaro and J. A. Wethington. In preparation. Sediment Budget for the North Illinois Shore from the Wisconsin Border to Wilmette Harbor. ERDC/CHL Technical Report. Vicksburg, MS: U.S. Army Engineer Research and Development Center.
} 
Table 6. Lake Michigan water levels at Station 9087044. Located at Calumet Harbor, IL, between 1939 and 2015.

\begin{tabular}{|c|c|c|c|}
\hline Image Date & Lake Level $(\mathrm{m})$ & Change from 2007 $(\mathrm{m})$ & Shoreline Adjustment $(\mathrm{m})$ \\
\hline $7 / 1 / 1939$ & 176.18 & 0.01 & 0.08 \\
\hline $7 / 15 / 1946$ & 176.96 & 0.79 & 7.21 \\
\hline $10 / 5 / 1974$ & 176.96 & 0.79 & 7.18 \\
\hline $4 / 1 / 1998$ & 176.81 & 0.64 & 5.84 \\
\hline $6 / 30 / 2004$ & 176.34 & 0.17 & 1.55 \\
\hline $7 / 7 / 2007$ & 176.17 & 0.00 & 0.00 \\
\hline $7 / 1 / 2010$ & 176.30 & 0.12 & 1.14 \\
\hline $8 / 10 / 2012$ & 176.25 & 0.08 & 0.72 \\
\hline $7 / 1 / 2015$ & 176.81 & 0.64 & 5.82 \\
\hline
\end{tabular}

As shown in Figure 12, from 1939 to 2015, the most significant erosion in the study area starts just south of the North Point Marina and runs $3 \mathrm{~km}$ (2 miles) to the Zion Nuclear Power Plant. From that point southward, the erosion becomes less significant until at a point just south of the Illinois Beach Resort where accretion begins to occur and increases in intensity until the north jetty of Waukegan Harbor is reached. The low, high, and average levels of erosion or accretion in the study area during the 79-year study are listed in Table 7. 
Figure 12. Shoreline change from North Point Marina to Waukegan Harbor from 1939 to 2015.

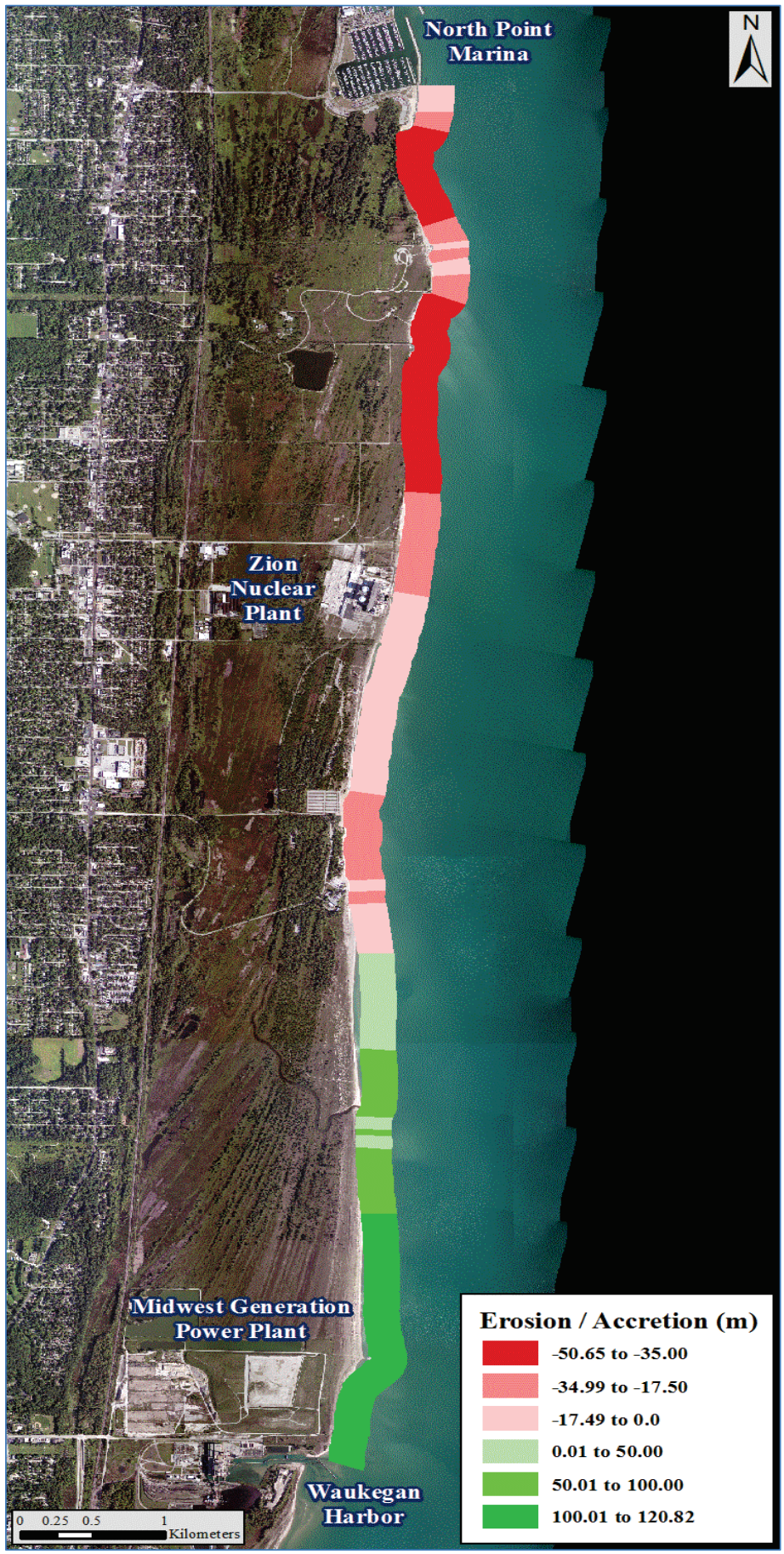


Table 7. Accretion or erosion values for the 79-year study of Waukegan Harbor, IL.

\begin{tabular}{|c|c|c|c|}
\hline Date Range & Range Low & Range High $(\mathrm{m})$ & Date Range \\
\hline 1939 to 1946 & -66.01 & 81.62 & -4.25 \\
\hline 1946 to 1974 & -152.74 & 103.61 & 39.17 \\
\hline 1974 to 1988 & -129.13 & 39.17 & -20.35 \\
\hline 1988 to 2004 & -32.93 & 98.47 & 32.86 \\
\hline 2004 to 2007 & -43.52 & 99.64 & 4.57 \\
\hline 2007 to 2010 & -47.16 & 31.16 & -5.43 \\
\hline 2010 to 2012 & -26.04 & 85.24 & 1.49 \\
\hline 2012 to 2015 & -55.84 & 41.87 & -13.15 \\
\hline 1939 to 2015 & -233.95 & 322.97 & -20.71 \\
\hline
\end{tabular}

Shoreline comparisons between 1939 and 1987 for a large area south of the North Point Marina have shown this shoreline receding at approximately $3 \mathrm{~m}$ (10 ft) per year (Chrzastowski et al. 1994). This shoreline change is shown in Figure 13, representing 1939 to 1946; Figure 14, representing 1946 to 1974; and Figure 15, representing 1974 to 1988 . Shortly after the North Point Marina was built in 1989, the beach to the south of it was converted into a parking lot. The beach was armored, and sediment was brought in to replace what had been eroded over the previous decades ${ }^{1}$. This prevented further shoreline erosion from the north $350 \mathrm{~m}(1,148 \mathrm{ft})$ of the study area, but it also prevents sediment from naturally moving south into the Illinois Beach State Park.

Possible factors for this high erosion rate include relatively high water levels for Lake Michigan, frequent substantial storms that generated larger waves than normal, and a lack of dredged materials being placed onshore or in the nearshore to help counteract the erosion.

\footnotetext{
${ }^{1}$ Morang, A., M. J. Chrzastowski, D. F. Bucaro and J. A. Wethington. In preparation. Sediment Budget for the North Illinois Shore from the Wisconsin Border to Wilmette Harbor. ERDC/CHL Technical Report. Vicksburg, MS: U.S. Army Engineer Research and Development Center
} 
Figure 13. Shoreline change from North Point Marina to Waukegan Harbor from 1939 to 1946.

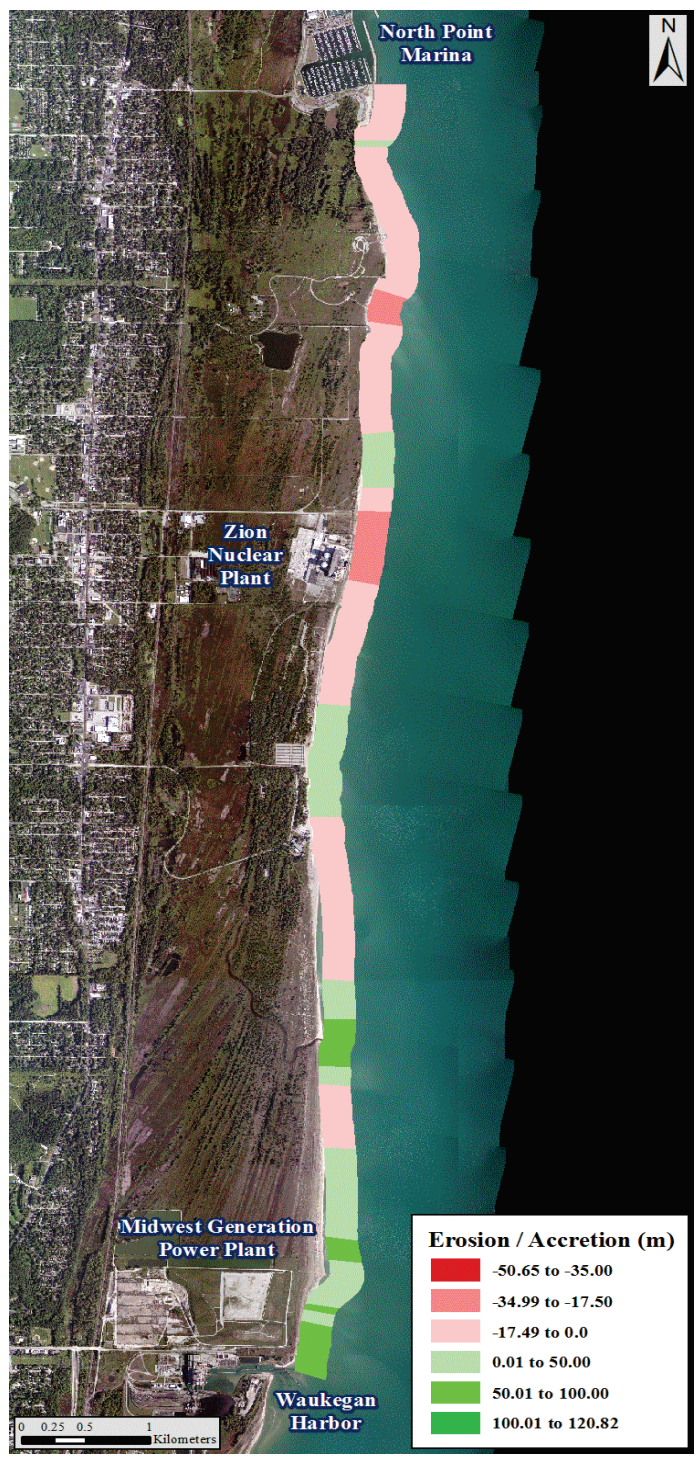

Figure 14. Shoreline change from North Point Marina to Waukegan Harbor from 1946 to 1974.

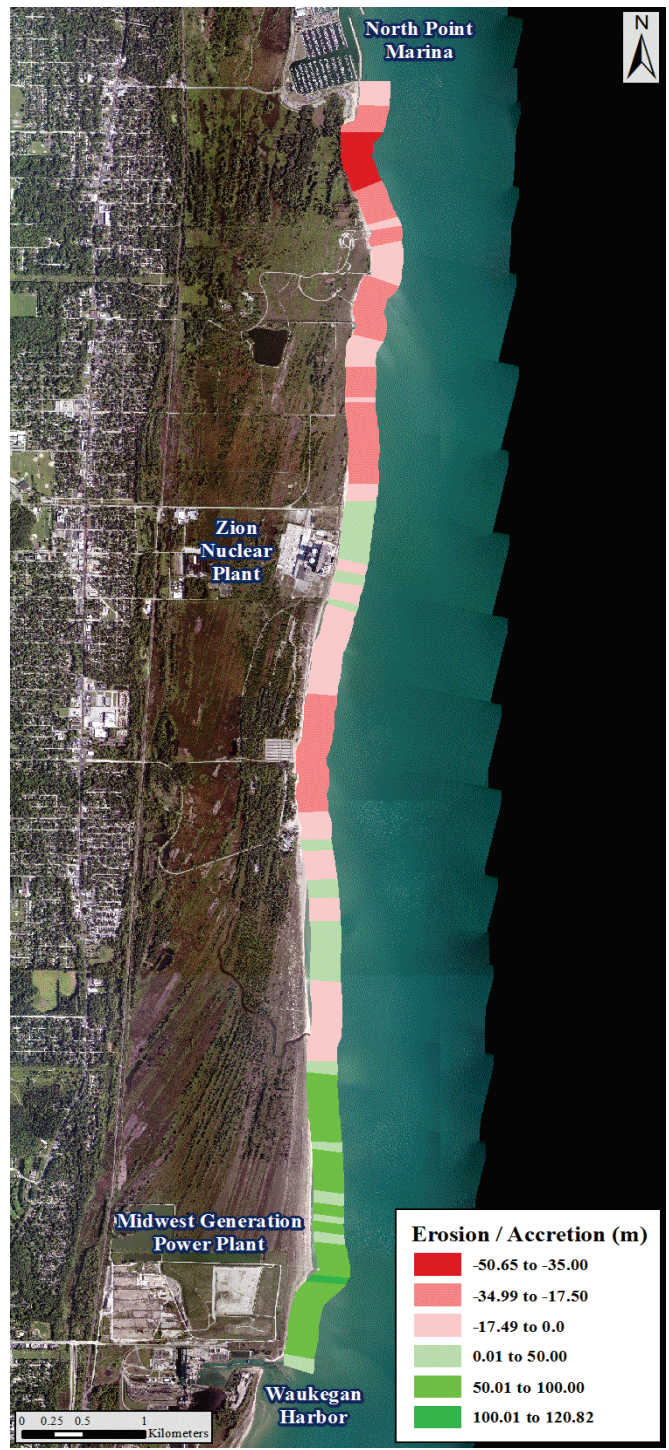

Beginning in 1999, dredged materials were placed in the nearshore area just to the south of North Point Marina. In this year, 47,000 m3 (62,000 yd3) of material were placed in the nearshore, with an average of $28,000 \mathrm{~m} 3$ $(36,000$ yd3) per year being placed in this location. The results of this beneficial practice can be seen in Figure 16 where the $11 \mathrm{~km}$ ( 7 miles) length of the study area became predominantly accretionary. This is also presented in Table 7 where the years 1988 to 2004 showed an average rate of accretion

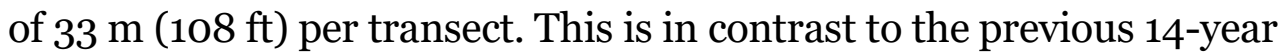
period of 1974 to 1988 showing an average erosion rate of $20 \mathrm{~m}$ (66 ft) per transect. 
Figure 15. Shoreline change from North Point Marina to Waukegan Harbor from 1974 to 1988.

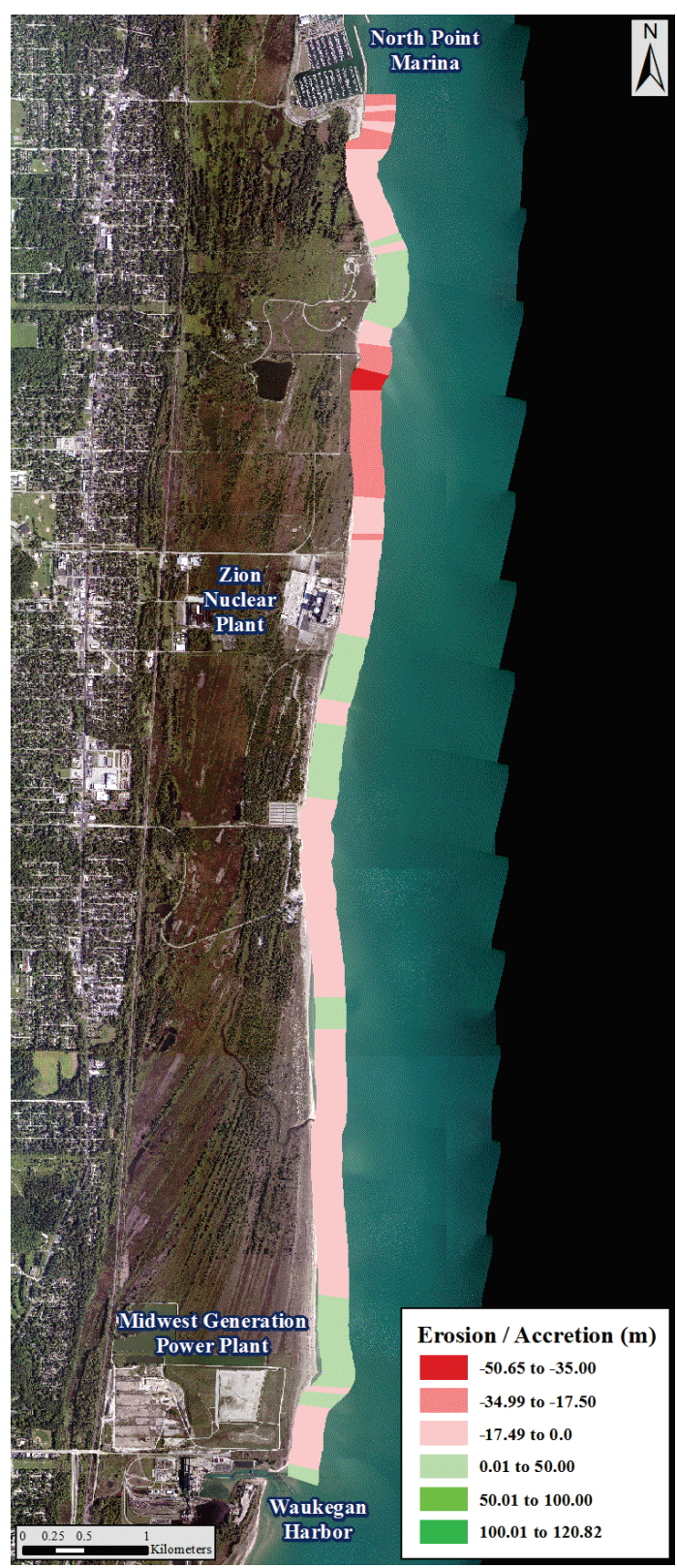

Figure 16. Shoreline change from North Point Marina to Waukegan Harbor from 1988 to 2004.

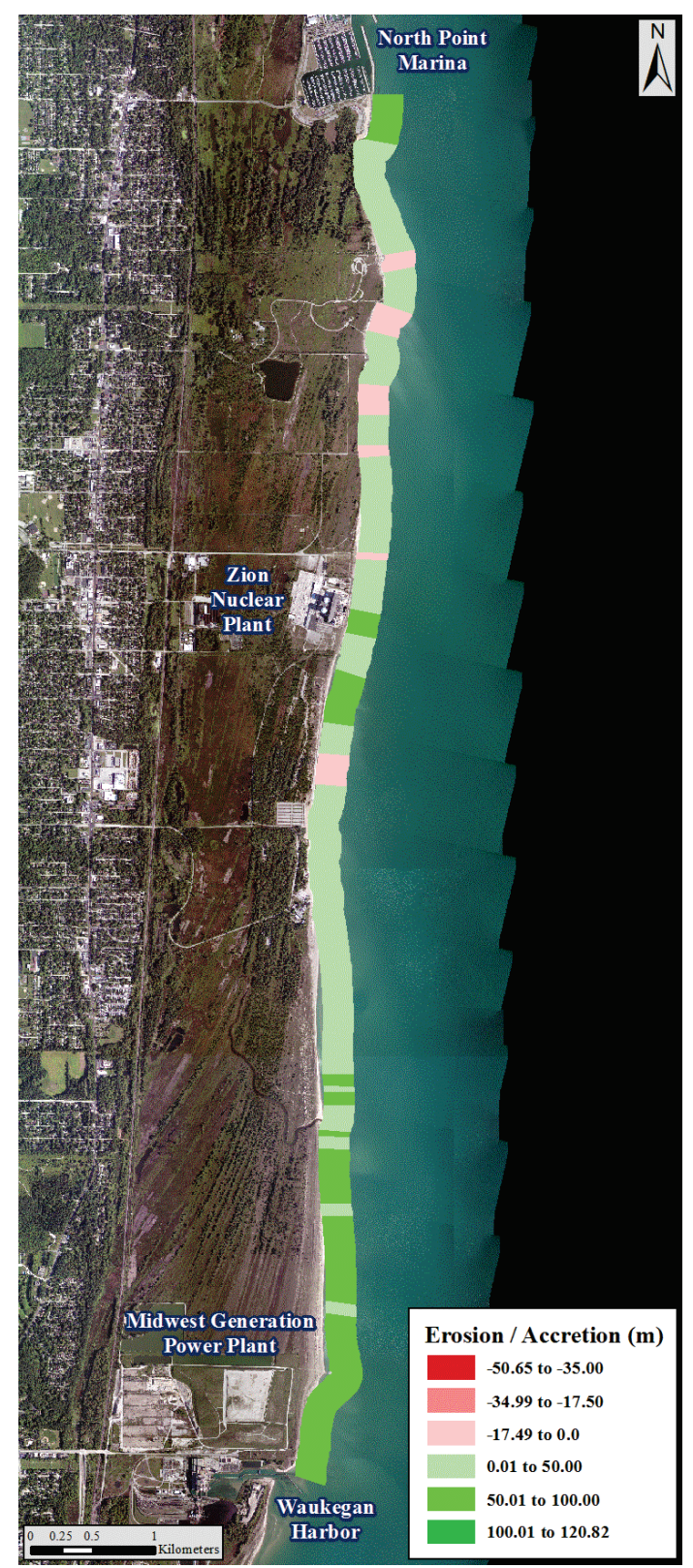

Between 2005 and 2013, an average of 35,000 m3 (46,000 yd3) per year of sediment was placed in the nearshore of Illinois Beach State Park and to the south of Waukegan Harbor. It appears this level of beach nourishment has, in general, helped to stabilize the shoreline across the study area. This is shown in Figure 17 from 2004 to 2007, in Figure 18 from 2007 to 2010, in Figure 19 from 2010 to 2012, and Figure 20 from 2012 to 2015. 
Figure 17. Shoreline change from North Point Marina to Waukegan Harbor from 2004 to 2007.

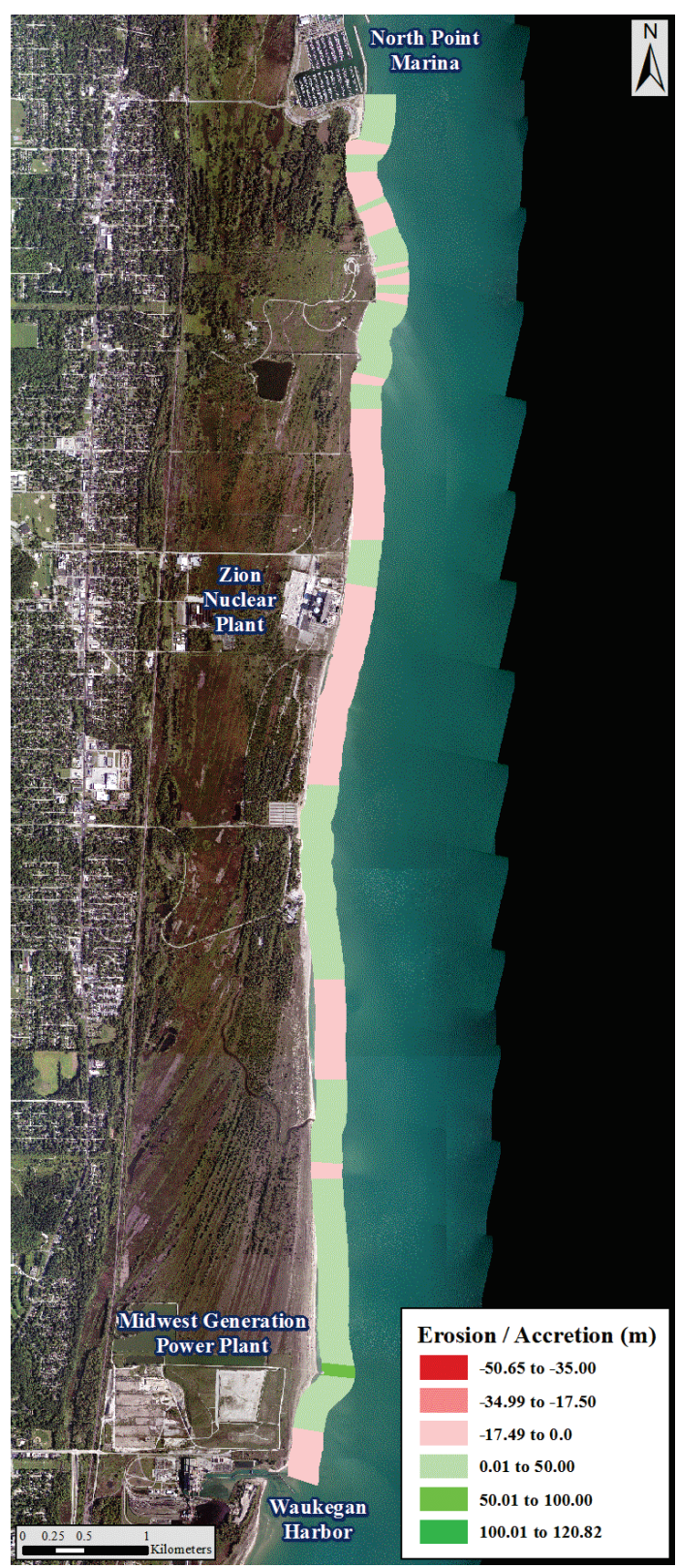

Figure 18. Shoreline change from North Point Marina to Waukegan Harbor from 2007 to 2010.

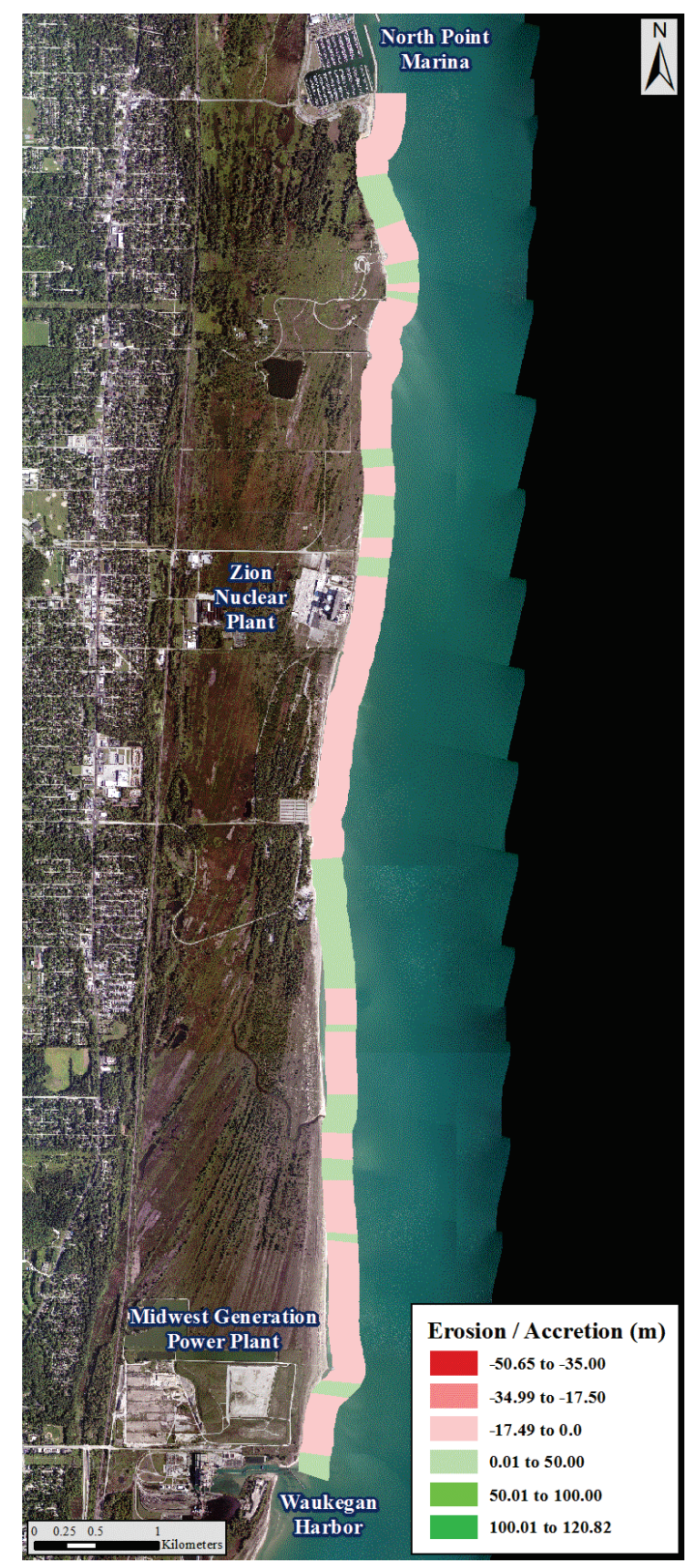


Figure 19. Shoreline change from North Point Marina to Waukegan Harbor from 2010 to 2012.

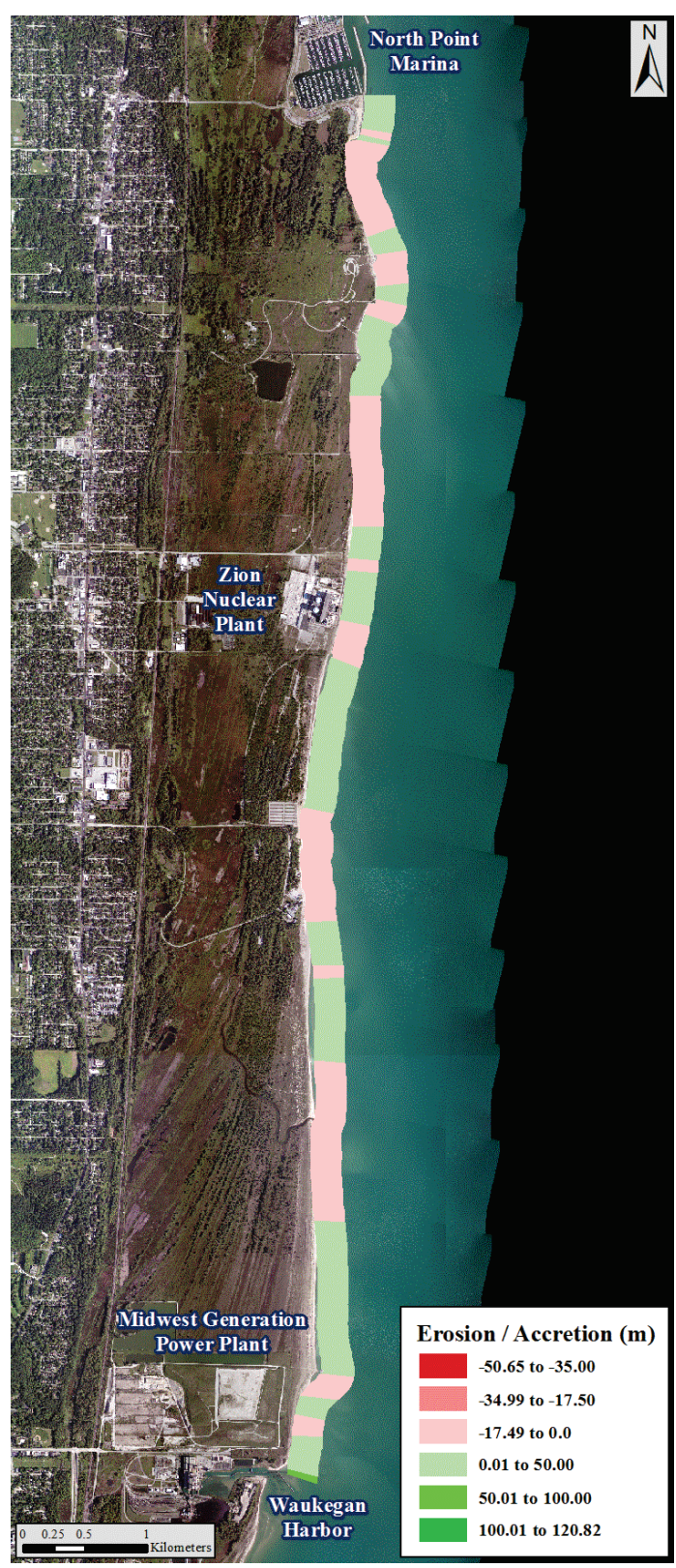

Figure 20. Shoreline change from North Point Marina to Waukegan Harbor from 2012 to 2015 .

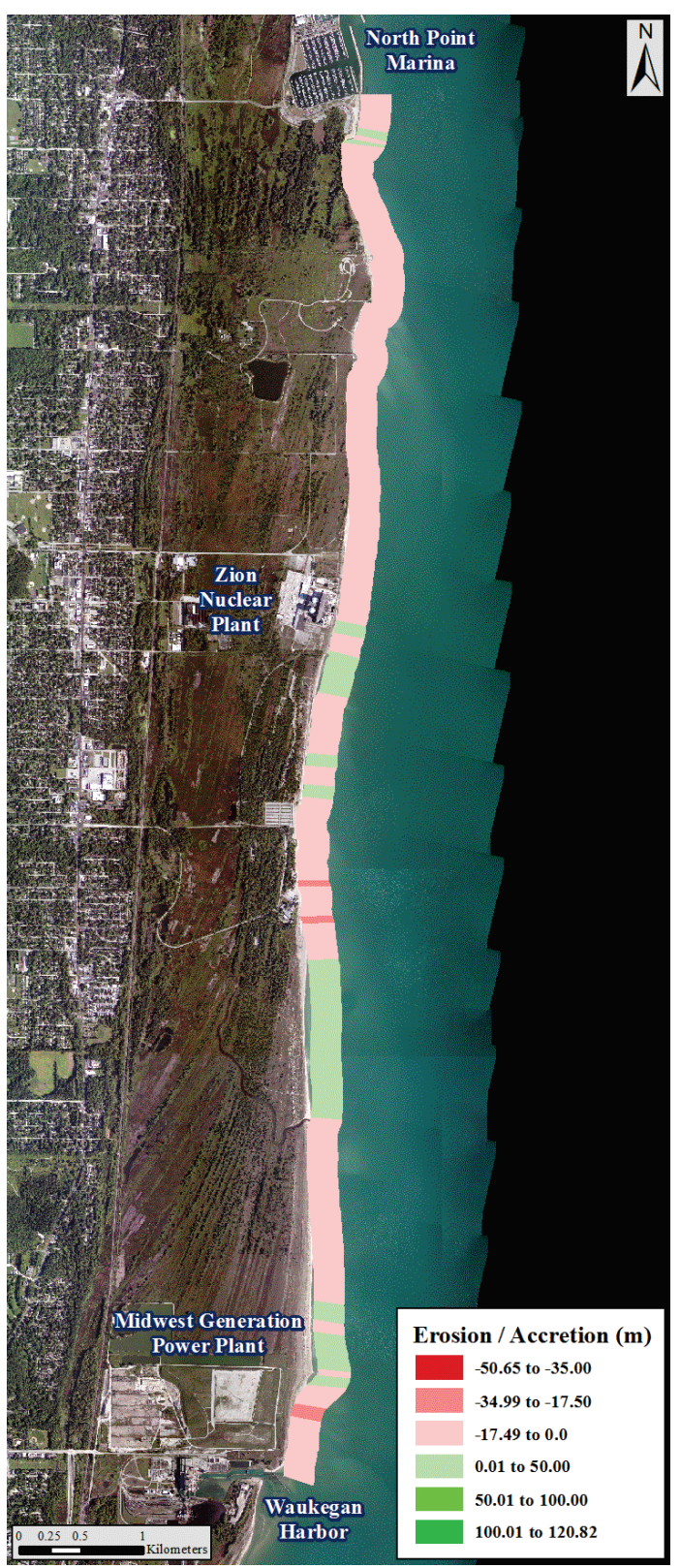

\subsection{SMT}

The SMT was applied at the Waukegan nearshore placement site. The frequency of sediment mobility and cross-shore sediment migration direction was calculated using the same methods as the Port of Indiana site. Wave hindcasts from WIS Station 94033 were applied to the nearshore placement site with regular waves from 1976 to 2014 and storm

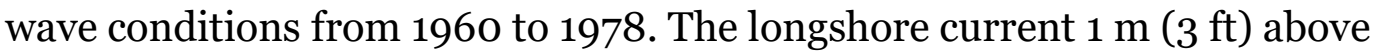
the bed was assumed to be $0.05 \mathrm{~m} / \mathrm{s}(0.16 \mathrm{ft} / \mathrm{s})$. A nearshore placement 
depth of $5.5 \mathrm{~m}(18 \mathrm{ft})$ was applied to the SMT, and the median grain size, $d_{50}$, for the dredged sediment is $0.15 \mathrm{~mm}$, thus matching the conditions applied at the Port of Indiana study area. To quantify the sensitivity of the SMT to the median grain size, which can vary, several grain sizes were applied to estimate the frequency of sediment mobilization and sediment migration direction at the Waukegan nearshore placement site (Table 8).

Table 8. Summary of the predicted sediment mobilization frequency and sediment migration directions for various grain sizes under typical and storm wave conditions.

\begin{tabular}{|c|c|c|c|c|}
\hline \multirow{2}{*}{$\begin{array}{c}\mathbf{d}_{50} \\
(\mathrm{~mm})\end{array}$} & \multicolumn{2}{|c|}{ Typical Waves } & \multicolumn{2}{c|}{ Storm Events } \\
\cline { 2 - 5 } & $\begin{array}{c}\text { Frequency of } \\
\text { Mobilization }\end{array}$ & $\begin{array}{c}\text { Sediment } \\
\text { Migration }\end{array}$ & $\begin{array}{c}\text { Frequency of } \\
\text { Mobilization }\end{array}$ & $\begin{array}{c}\text { Sediment } \\
\text { Migration }\end{array}$ \\
\hline 0.1 & $36 \%-50 \%$ & $66 \%$ Onshore & $66 \%-81 \%$ & $54 \%$ Onshore \\
\hline 0.15 & $32 \%-44 \%$ & $93 \%$ Onshore & $60 \%-75 \%$ & $85 \%$ Onshore \\
\hline 0.2 & $29 \%-39 \%$ & $98 \%$ Onshore & $56 \%-70 \%$ & $95 \%$ Onshore \\
\hline 0.3 & $25 \%-33 \%$ & $100 \%$ Onshore & $49 \%-62 \%$ & $100 \%$ Onshore \\
\hline
\end{tabular}

In Table 8 , the $d_{50}$ of $0.15 \mathrm{~mm}$ was estimated to be accretionary under typical and storm wave conditions. It is interesting to note the accretionary storm wave conditions, because storms generally cause erosion at this site. Although storms from 1960 to 1978 were determined using nine water level gauges in Lake Michigan to identify storm surge conditions, it is possible these storms were less intense. The frequency of sediment mobility is less at the Waukegan placement site than at the Port of Indiana placement site. This indicates that the sediment will likely move more slowly at the Waukegan nearshore placement site but will likely move onshore. Figure 21 shows wave roses for typical and storm wave conditions to estimate the dominant axis of wave induced sediment transport. Both wave roses have easterly resultant vectors, and the typical waves have a slight northerly component in the resultant vector, indicating a southerly longshore transport direction under typical waves. 
Figure 21. Wave rose of the wave direction and zero moment wave height $\left(H_{m o}\right)$ at the Waukegan nearshore placement site from a) typical waves from 1976 to 2014 and b) storms waves from 1960 to 1978 . The resultant wave direction vector during typical waves is $76^{\circ}$ from north and during storm waves is $91^{\circ}$ from north. Thus the resultant vector is propagating from an easterly direction under both wave conditions.

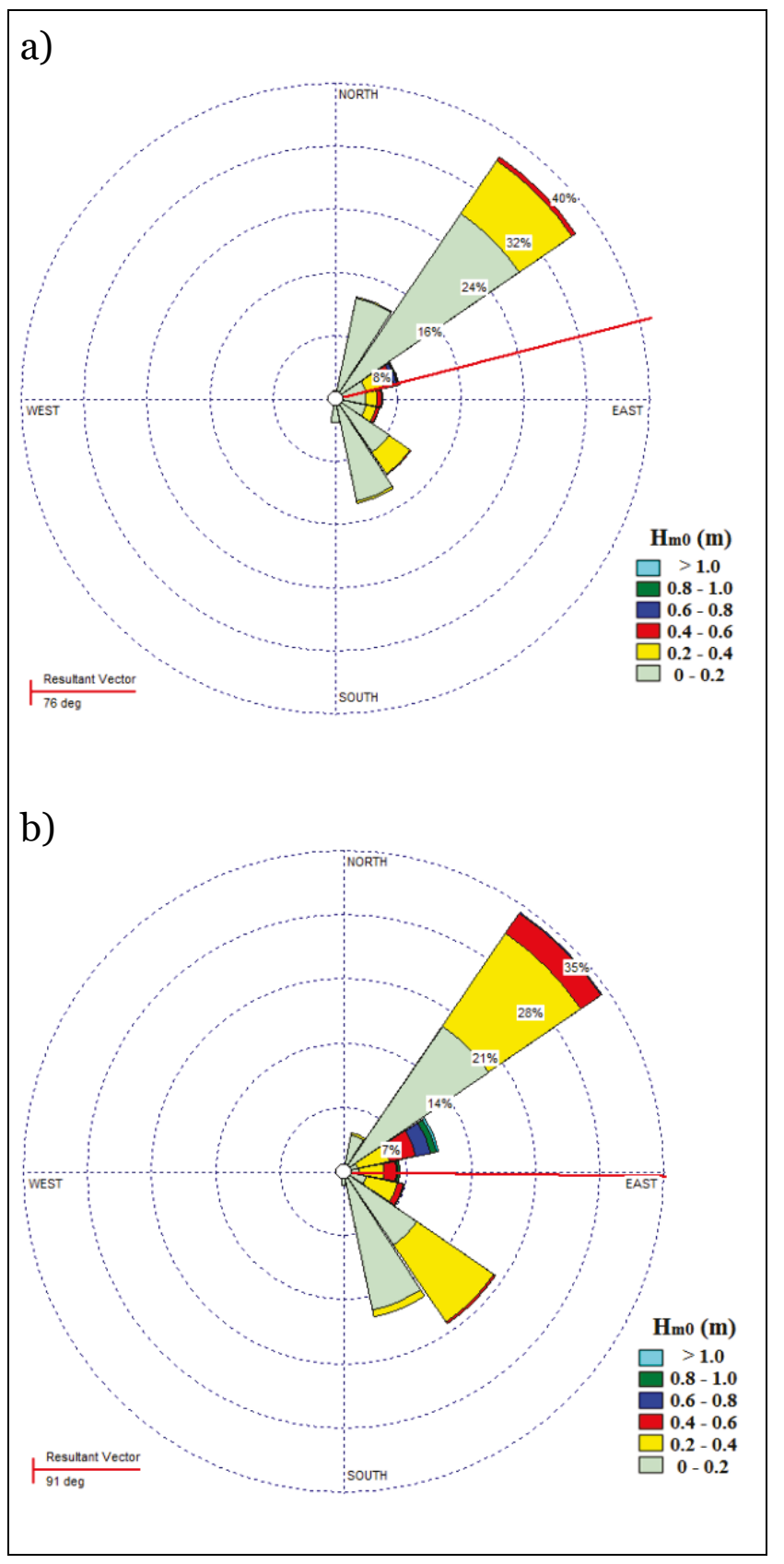




\section{Innovative Placement Techniques}

In the summer of 2015, researchers from the U.S. Army Engineer Research and Development Center (ERDC) teamed with engineers from the USACE Jacksonville District to study a nearshore placement project in St. Johns County, Florida. Operations and maintenance dredging of St. Augustine Inlet by the USACE Wilmington District special operations split hull hopper dredge Murden began in late July, with approximately 115,000 m3 $(150,000 \mathrm{yd} 3)$ of material placed in the nearshore of Vilano Beach. Two nearshore berm shapes were constructed to study the shape effects on the morphologic evolution. One berm was constructed as an elongated bar, while the other berm was constructed as a mound shape. The dredge was instructed to construct the nearshore berms by "nosing in" along a predefined shore-perpendicular placement or heading line and then split the hopper to place the sediment as shallow as possible given the tide. The nearshore berms were constructed in depths 2-4 m (5-12 ft). The shallow placement of the dredged material increased sediment mobility and waves were noted to be visibly breaking over both nearshore berms after placement operations (McFall et al. 2017).

The geomorphic changes to the nearshore berms were tracked with bathymetric surveys and the Radar Inlet Observing System. The shoreline accretion on the lee side of the nearshore berms is clearly shown in the shoreline change between the preconstruction survey and the survey 4 months after construction using mean high-high water (MHHW) tidal datum in Figure 22. A mild shoreline accretion was observed on the lee side of the bar-shaped northern berm while a more peaked shoreline cusp was observed on the lee side of the mound-shaped southern berm. These results substantiate the use of nearshore berms as a beneficial use of dredged sediment to protect the shoreline and keep the sediment in the littoral system. This is likely due to the reduced wave energy on the lee side of the nearshore berm caused by wave breaking (Brutsché and McFall 2016; Brutsché et al. 2017). Lessons learned from this project can be directly applied to the nearshore placement sites in Lake Michigan. 
Figure 22. Vilano Beach, Florida, shoreline change using the MHHW tidal datum between preconstruction and 4 months after nearshore berm construction. Note the positive shoreline change on the lee side of the nearshore berms.

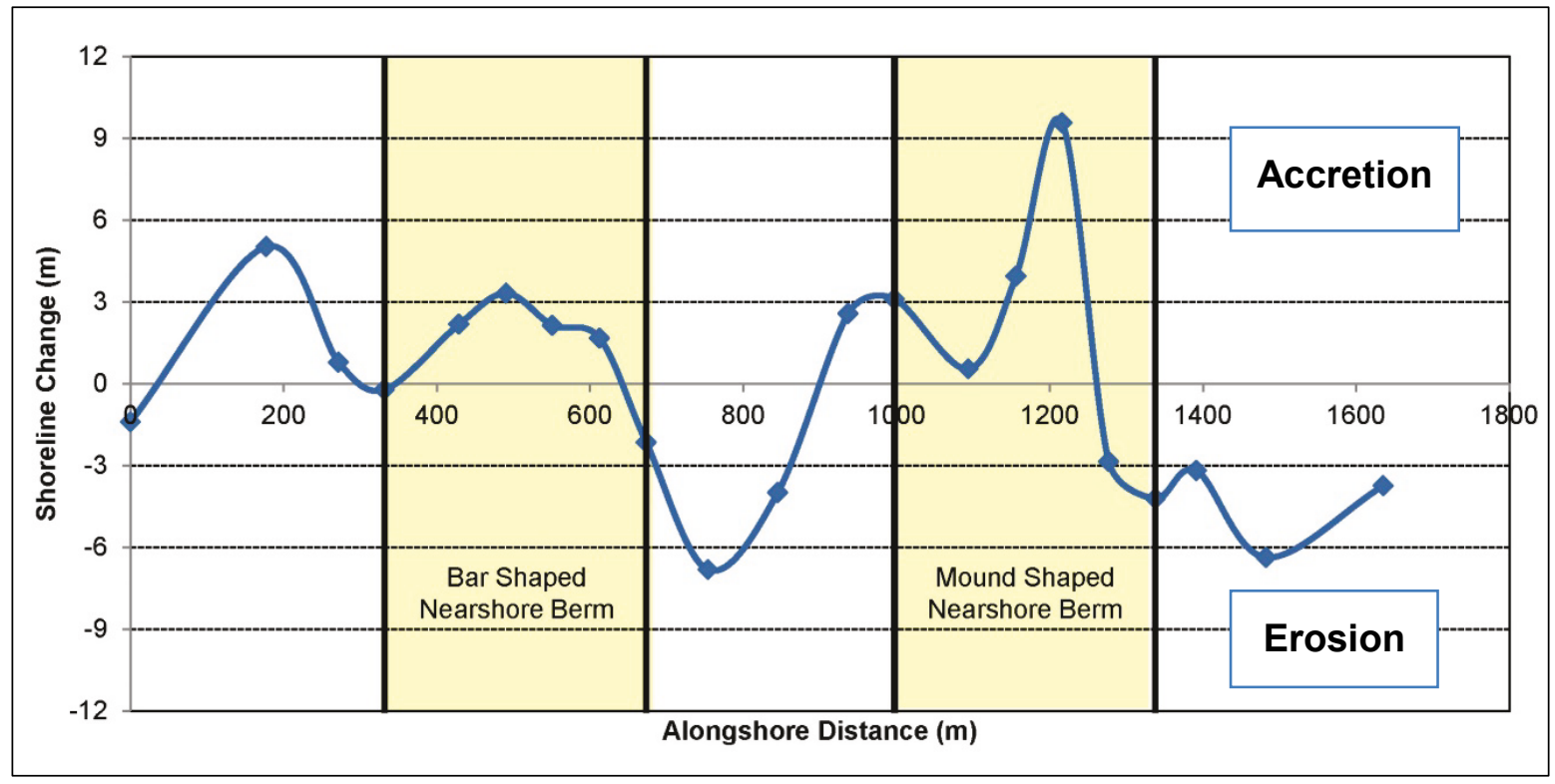

The wave climate for both nearshore placement sites in Lake Michigan is conducive to accretionary sediment migration for dredged material placed in the nearshore, but the speed of the sediment transport, estimated using the frequency of sediment mobility, is greatly dependent on the placement depth as shown in previous studies (Hands and Allison 1991; Bryant and McFall 2016). Current nearshore placement practices in the region allow

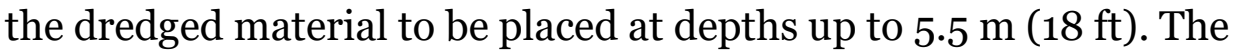
dredging scow operators prefer to place the material in the deepest possible location with small discrete placement mounds to prevent the sediment from obstructing the hanging gates of the scow from closing. By placing the material in small discrete mounds at the deepest allowable depth, minimal wave energy is being dissipated over the nearshore placement and there is minimal sediment transport of the nearshore placement, either onshore or offshore.

Placing the dredged sediment in shallower water in the shape of a berm, or contiguous mound, will likely increase the sediment mobility and increase wave energy dissipation over the berm, thereby protecting the beach shoreline. The tug and scow operations of the placement activity could be constrained to ensure placement in an elongated, contiguous feature by requiring placement of dredged sediment within a smaller area of the larger permitted placement area. The contractor could also be provided with recommended placement or heading lines to construct a specific 
designed shape. Modification of the existing hanging gate design, common to scows in the Great Lakes, or light loading the existing scows to reduce the draft may be required for the shallower placement of dredged sediment adjacent to previous placement locations required for nearshore berm construction. 


\section{Conclusions}

The historical imagery has been analyzed to assess the shoreline change and the influence of current nearshore placement practices of dredged material from the Port of Indiana and Waukegan Harbor. Significant erosion was observed in the 1988 shoreline on the lee side of the Waukegan placement site after the highly erosive conditions of high water levels and several storms in the mid-1980s. The shoreline change results for the 1990 s and 2000s indicated that the shoreline position largely recovered due to the increased practice of nearshore placement of locally dredged sediment. Similar results were observed with the Port of Indiana placement site shoreline. The dramatic water level increase observed in Lake Michigan from 2013 to 2014 may partially account for the recent beach erosion as the SMT predicted cross-shore sediment migration for both sites to have accretionary conditions under typical waves.

The current nearshore placement technique consists of placing sediment

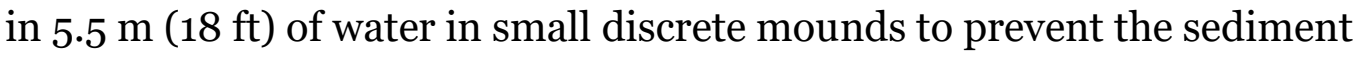
from obstructing the hanging gates of the scow from closing. The sediment will be mobilized and transported much faster if placed in shallower depths. More wave energy will be dissipated from the dredged sediment if the material is placed in the shape of a nearshore berm or artificial sandbar. This initial analysis of the current placement practices indicates an accretionary effect on the shoreline, but further analysis and monitoring is needed to quantify the shoreline response.

Some minor changes to the placement technique, such as placing the dredge sediment in a discrete bar form in shallower water, could make the nearshore placements more successful with regards to nourishing the subaerial shoreface. One method to potentially accomplish this is by restricting the placement area for a project to a much smaller area in the larger permitted nearshore placement area and light loading the scows to reduce the draft for shallower placement. 


\section{References}

Bryant, D. B., and B. C. McFall. 2016. "Transport of Nearshore Dredge Material Berm." In Proceedings, CoastLab 2016, Ottawa, Canada, 10-13 May 2016.

Brutsché, K. E., and B. C. McFall. 2016. "Research on Nearshore Placement at Vilano Beach, Florida." Coastal Voice, 11-12.

Brutsché, K. E., B. C. McFall, H. Li, J. E. McNinch, J. D. Ousley, J. A. Engle, and C. K. Maglio. 2017. "Strategic Nearshore Placement of Dredged Sediment at Vilano Beach, Florida." Shore and Beach 85(3): 77-84. http://asbpa.org/wpv2/wpcontent/uploads/2016/03/aTableofContents-2017v3.pdf.

Chrzastowski, M. J., T. A. Thompson, and C. B. Trask. 1994. "Coastal Geomorphology and Littoral Cell Divisions along the Illinois-Indiana Coast of Lake Michigan.” Journal of Great Lakes Research 20(1):27-43.

Gronewold, A. D., J. Bruxer, D. Durnford, J. P. Smith, A. H. Clites, F. Seglenieks, S. S. Qian, T. S. Hunter, and V. Fortin. 2016. "Hydrological Drivers of Record-Setting Water Level Rise on Earth's Largest Lake System.” Water Resources Research 52(5): 4026-4042.

Hallermeier, R. J. 1981. "A Profile Zonation for Seasonal Sand Beaches from Wave Climate." Coastal Engineering 4:253-277.

Hands, E. B., and M. C. Allison. 1991. "Mound Migration in Deeper Water and Methods of Categorizing Active and Stable Depths. In Proceedings, Coastal Sediments, 1991. Edited by N. C. Kraus, K. J. Gingerich, and D. L. Kriebel, 1985-1999. New York: American Society of Civil Engineers.

Larson, M., and N. C. Kraus. 1992. Analysis of Cross-Shore Movement of Natural Longshore Bars and Material Placed to Create Longshore Bars. Technical Report DRP-92-5. Vicksburg, MS: U.S. Army Engineer Waterways Experiment Station.

Lillycrop, L. S., J. W. McCormick, L. E. Parson, and M. A. Chasten. "Adaptive Management through Regional Sediment Management." In Proceedings of the Western Dredging Association (WEDA XXXI) Technical Conference and Texas A\&M University (TAMU 42) Dredging Seminar, Nashville, Tennessee, June 5-8, 2011.

McFall, B. C., K. E. Brutsché, J. D. Ousley, C. K. Maglio, and J. A. Engle. 2017. "Innovative Nearshore Berm Placement Techniques at Vilano Beach, FL and Application of the Sediment Mobility Tool." World of Dredging 51(1/2): 34-35.

McFall, B. C., S. J. Smith, C. E. Pollock, J. Rosati, III, and K. E. Brutsché. 2016. Evaluating Sediment Mobility for Siting Nearshore Berms. ERDC/CHL CHETNIV-108. Vicksburg, MS: U.S. Army Engineer Research and Development Center. 
Morang, A., A. E. Frey, D. F. Bucaro, and S. Brodzinsky. 2015. Sediment Budget on the Indiana Shore at Burns Harbor, Lake Michigan. Vicksburg, MS: U.S. Army Engineer Research and Development Center. Chicago, IL: USACE Chicago District.

National Oceanic and Atmospheric Administration (NOAA), Center for Operational Oceanographic Products and Services. 2013. Calumet Harbor, Illinois - Station ID: 9087044. Accessed 25 Oct 2017. http://tidesandcurrents.noaa.gov/stationhome.html?id=9087044.

Shabica, C., and F. Pranschke. 1994. "Survey of Littoral Drift Sand Deposits along the Illinois and Indiana Shores of Lake Michigan." Journal of Great Lakes Research 20(1):61-72.

Thieler, E. R., E. A. Himmelstoss, J. L. Zichichi, and E. Ayhan. 2008. Digital Shoreline Analysis System (DSAS) Version 4.o-An ArcGIS Extension for Calculating Shoreline Change. U.S. Geological Survey Open File Report 1278.

U.S. Army Corps of Engineers, Chicago District (USACE LRC). 1995. Burns Small Boat Harbor Monitoring Program Portage County, Indiana. 3, 5, 10, and 30. Chicago, IL: USACE Chicago District.

USACE LRC. 2008. Indiana Shoreline Monitoring: Burns International Harbor to Michigan City Harbor. 39. Buffalo, NY: U.S. Army Corps of Engineers.

Wood, W. L., L. J. Madalon, and C. L. Wood. 1990. NIPSCO Beach Nourishment Sediment Evaluation for Southern Lake Michigan. 8-12. West Lafayette, IN: SEACO Inc. 


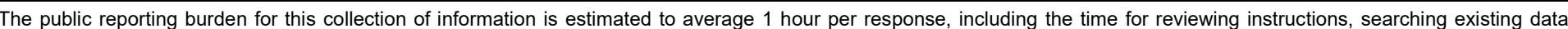

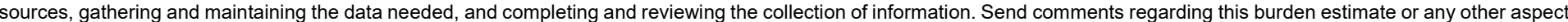

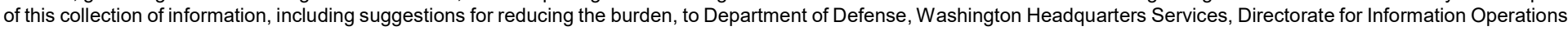

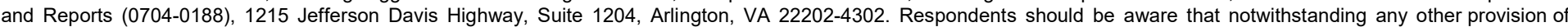
law, no person shall be subject to any penalty for failing to comply with a collection of information if it does not display a currently valid OMB control number. PLEASE DO NOT RETURN YOUR FORM TO THE ABOVE ADDRESS.
1. REPORT DATE
March 2018
2. REPORT TYPE
3. DATES COVERED (From - To)
Final Report

4. TITLE AND SUBTITLE

Nearshore Placement Techniques in Southern Lake Michigan

5a. CONTRACT NUMBER

5b. GRANT NUMBER

5c. PROGRAM ELEMENT NUMBER

6. AUTHOR(S)

David E. Arnold, Brian C. McFall, Katherine E. Brutsché, Erin C. Maloney, and David F. Bucaro

5d. PROJECT NUMBER

462581

5e. TASK NUMBER

5f. WORK UNIT NUMBER

7. PERFORMING ORGANIZATION NAME(S) AND ADDRESS(ES) (see reverse)

8. PERFORMING ORGANIZATION REPORT NUMBER

ERDC/CHL TR-18-3

9. SPONSORING/MONITORING AGENCY NAME(S) AND ADDRESS(ES)

10. SPONSOR/MONITOR'S ACRONYM(S)

U.S. Army Corps of Engineers

USACE

Washington, DC 20314-1000

11. SPONSOR/MONITOR'S REPORT NUMBER(S)

12. DISTRIBUTION/AVAILABILITY STATEMENT

Approved for public release; distribution is unlimited.

\section{SUPPLEMENTARY NOTES}

\section{ABSTRACT}

The shorelines near the Port of Indiana and Waukegan Harbor in southern Lake Michigan were analyzed using historical aerial photography, direct beach and nearshore placement records, and the U.S. Geological Survey Digital Shoreline Analysis System. The shoreline analysis was compared to the results of the U.S. Army Corps of Engineers Sediment Mobility Tool. High water levels and significant storms led to erosive conditions in the 1980s. During the 1990s and 2000s, nearshore placement of locally dredged sediment likely contributed to the recovery of these shorelines. The current nearshore placement technique consists of placing sediment in 5.5 meters (18 feet) of water in small discrete mounds to prevent the sediment from obstructing the hanging gates of the scow from closing. The sediment will be mobilized more frequently, and more energy will be dissipated if the dredged sediment is placed in shallower depths in the shape of an elongated bar or mound. Two potential methods to accomplish this are to restrict the placement area for a project to a much smaller area in the larger permitted nearshore placement area and to light load the scows to reduce the draft for shallower placement.

\section{SUBJECT TERMS}

Dredging, Dredging spoil, Environmental management, Michigan, Lake-Shorelines, Sedimentation and deposition, Sediment transport, Shorelines-Monitoring

\section{SECURITY CLASSIFICATION OF:}

\begin{tabular}{|l|l|l|l}
\hline a. REPORT & b. ABSTRACT & c. THIS PAGE & ABSTRACT \\
Unclassified & Unclassified & Unclassified & SAR
\end{tabular}

18. NUMBER 19a. NAME OF RESPONSIBLE PERSON OF PAGES Brian McFall

43 19b. TELEPHONE NUMBER (Include area code) 601-634-6015 
7. PERFORMING ORGANIZATION NAME(S) AND ADDRESS(ES)

(continued)

Coastal and Hydraulics Laboratory

U.S. Army Engineer Research and Development Center

3909 Halls Ferry Road, Building 3200

Vicksburg, Mississippi 39180

U.S. Army Corps of Engineers, Chicago District

231 S. LaSalle Street, Suite 1500

Chicago, Illinois 60604 